\title{
Guttiferone A aggregates modulate Silent Information Regulator 1 (SIRT1) activity
}

Kévin Cottet, ${ }^{\mathrm{a}}$ Bin Xu, ${ }^{\mathrm{b}}$ Pascale Coric, ${ }^{\mathrm{c}}$ Serge Bouaziz, ${ }^{\mathrm{c}}$ Sylvie Michel, ${ }^{\mathrm{a}}$ Michel Vidal, ${ }^{\mathrm{b}, \mathrm{c}}$ Marie-Christine Lallemand, ${ }^{\text {a Sylvain Broussy }}{ }^{*}$,

${ }^{a}$ Laboratoire Pharmacognosie, Chimie des Substances Naturelles, Electrochimie UMR COMETE 8638 CNRS, Université Paris Descartes, Faculté de Pharmacie de Paris, Sorbonne Paris Cité, 4 av. de l'Observatoire, Paris 75006 France

${ }^{\mathrm{b}}$ Laboratoire Hétérocycles et Peptides : Approche Ciblée, Cancer et Angiogenèse UMR COMETE 8638 CNRS, Université Paris Descartes, Faculté de Pharmacie de Paris, Sorbonne Paris Cité, 4 av. de l'Observatoire, Paris 75006 France

c Laboratoire de Cristallographie et RMN Biologiques, UMR 8015 CNRS, Université Paris Descartes, Faculté de Pharmacie de Paris, Sorbonne Paris Cité, 4 av. de l'Observatoire, Paris 75006 France

dUF Pharmacocinétique et Pharmacochimie, hôpital Cochin, AP-HP, 27 rue du Faubourg Saint Jacques, Paris 75014, France

Additional SIRT1 activity assay results

$\begin{array}{ll}\text { Trypsin activity assay results } & 6\end{array}$

$\begin{array}{ll}\text { Additional NMR results } & 7\end{array}$

$\begin{array}{ll}\text { DLS results } & 23\end{array}$

$\begin{array}{ll}\text { Representative HPLC chromatograms } & 27\end{array}$ 
Additional SIRT1 activity assay results.
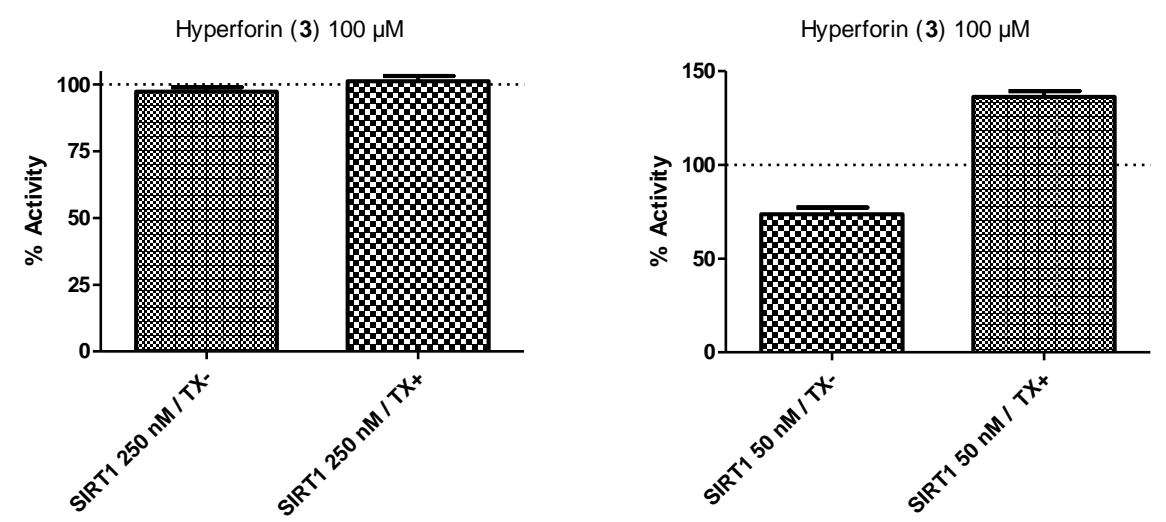

Figure S1. Percent SIRT1 activity in the presence of $100 \mu \mathrm{M}$ of hyperforin (3), compared to activity under the same assay conditions in the absence of 3. TX-: absence of Triton X-100. TX+: presence of $0.01 \%$ Triton X-100 (v:v). Error bars are SD from the mean of at least 2 experiments.

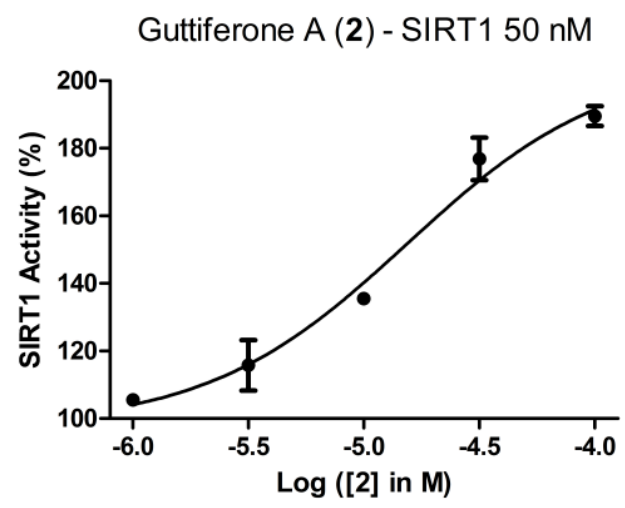

\begin{tabular}{|c|l|}
\hline LogEC50 & -4.813 \\
EC50 & $1.537 \mathrm{e}-005$ \\
\hline Span & 108.4 \\
Std. Error & \\
Bottom & 4.609 \\
Top & 5.840 \\
LogEC50 & 0.1081 \\
Span & 5.597 \\
$95 \%$ Confidence Intervals & \\
\hline Bottom & 86.87 to 108.1 \\
\hline Top & 192.5 to 219.4 \\
LogEC50 & -5.063 to -4.564 \\
\hline EC50 & $8.658 \mathrm{e}-006$ to $2.728 \mathrm{e}-005$ \\
Span & 95.53 to 121.3 \\
Goodness of Fit & \\
Degrees of Freedom & 8 \\
\hline$R^{2}$ & 0.9803 \\
\hline Absolute Sum of Squares & 254.5 \\
Sy.x & 5.640 \\
Number of points & 11 \\
Analyzed & 11 \\
\hline
\end{tabular}

Figure S2. Dose-effect curve for guttiferone A (2) on SIRT1 activity in the presence of TX-100 $(0.01 \% \mathrm{v}: \mathrm{v})$. The table summarizes the results of a nonlinear regression analysis with the "log (agonist) vs response" function in the GraphPad Prism software. Error bars are SD from the mean of at least 2 experiments. 

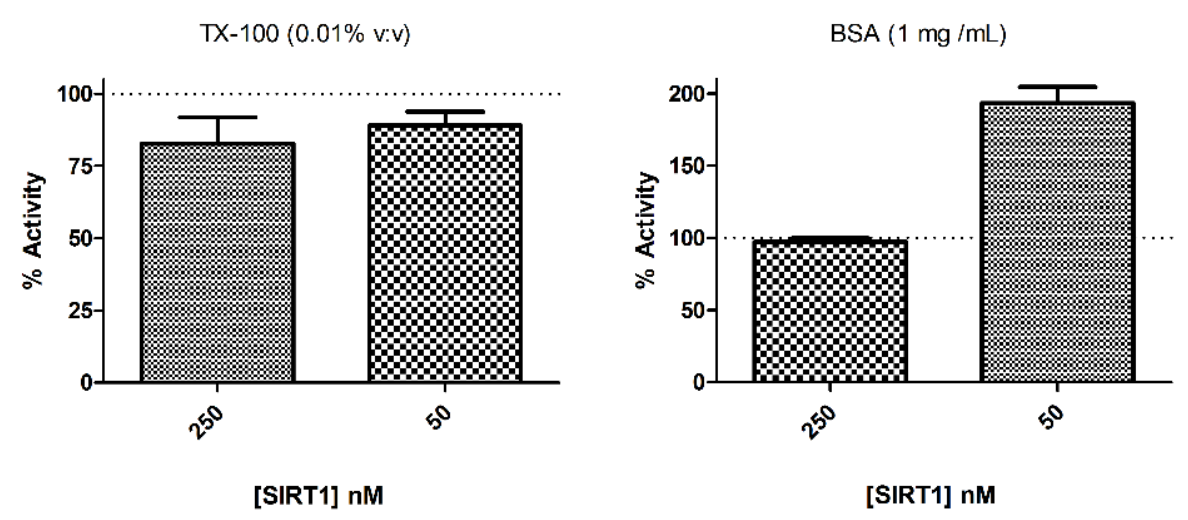

Figure S3. Effect of TX100 (0.01\% v:v) and BSA (1 mg / mL) on SIRT1 activity. Percent SIRT1 activity is calculated from activity under the same assay conditions in the absence of additive. Error bars are SD from the mean of at least 2 experiments.

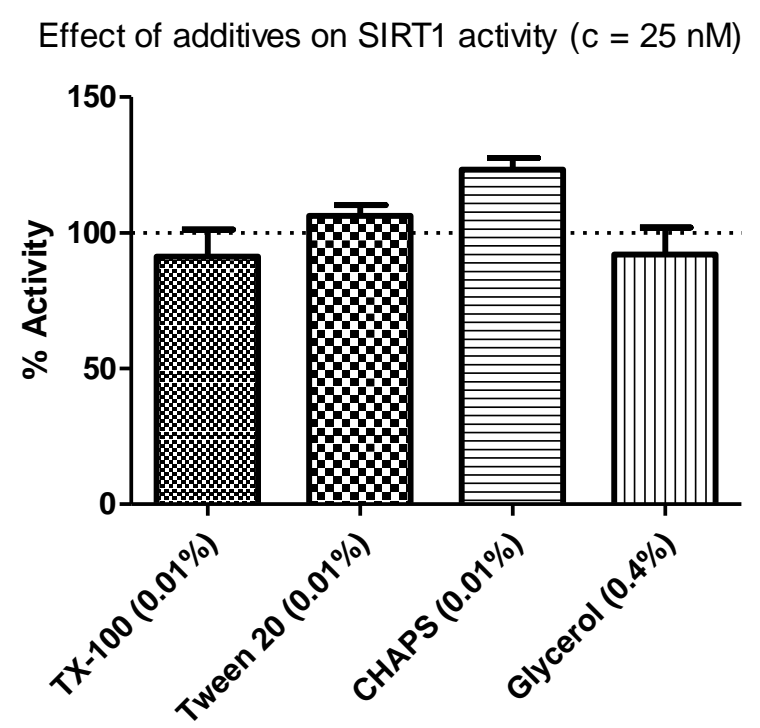

Figure S4. Effect of indicated additive on SIRT1 activity, with [SIRT1] $=25 \mathrm{nM}$. The concentrations of additives are expressed as final \% v/v in the reaction mixtures (except for CHAPS, for which is it a mass concentration). Error bars are SD from the mean of at least 3 experiments. 


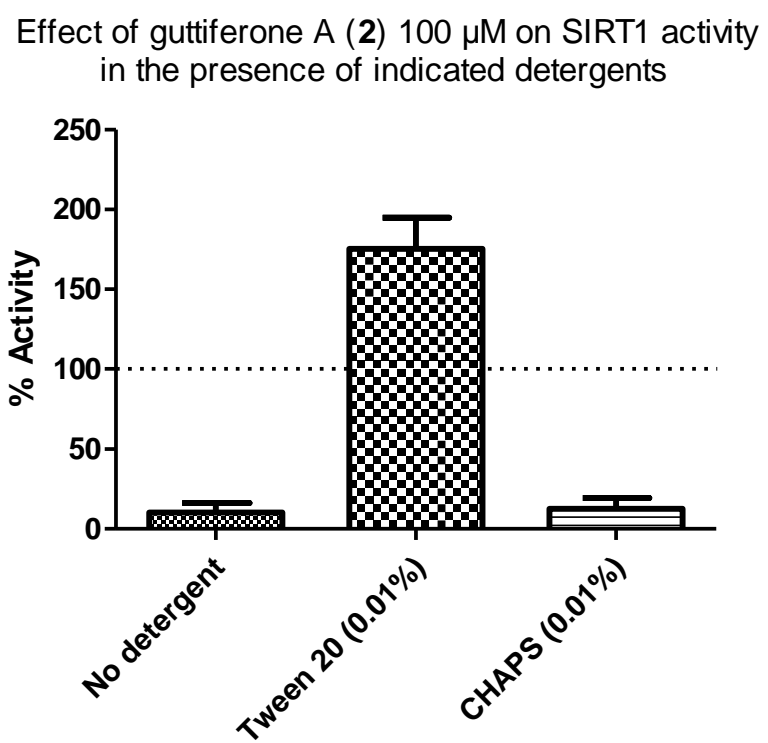

Figure S5. Percent SIRT1 activity in the presence of $100 \mu \mathrm{M}$ guttiferone A (2), compared to activity under the same assay conditions in the absence of 2 . For all experiments: [SIRT1] $=25 \mathrm{nM}$. The concentrations of additives are expressed as final $\% \mathrm{v} / \mathrm{v}$ in the reaction mixtures (except for CHAPS, for which is it a mass concentration). Error bars are SD from the mean of at least 3 experiments.

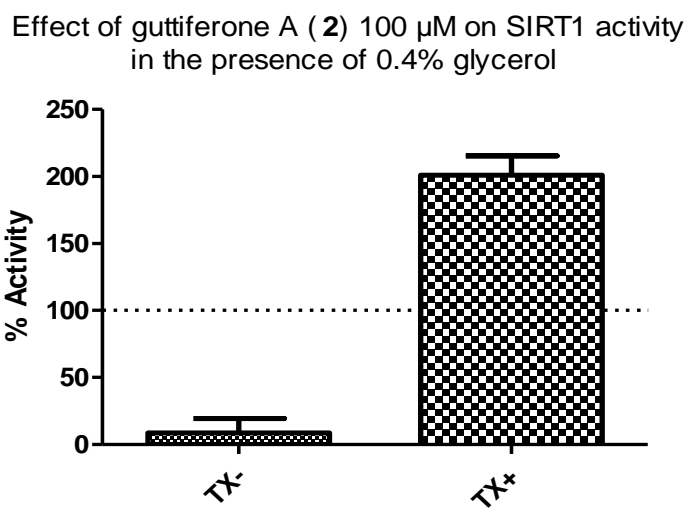

Figure S6. Percent SIRT1 activity in the presence of $100 \mu \mathrm{M}$ guttiferone A (2), compared to activity under the same assay conditions in the absence of $\mathbf{2}$. Conditions for all experiments: [SIRT1] $=25 \mathrm{nM}$ and $0.4 \% \mathrm{v} / \mathrm{v}$ final glycerol concentration (by addition of $2 \mu \mathrm{L}$ of a $10 \%$ solution in water, to a final volume of $50 \mu \mathrm{L}$ ). TX-: absence of Triton X-100. TX+: presence of 0.01\% Triton X-100 (v:v). Error bars are SD from the mean of at least 3 experiments. 
Guttiferone A (2) $100 \mu \mathrm{M}$, SIRT1 $25 \mathrm{nM}$

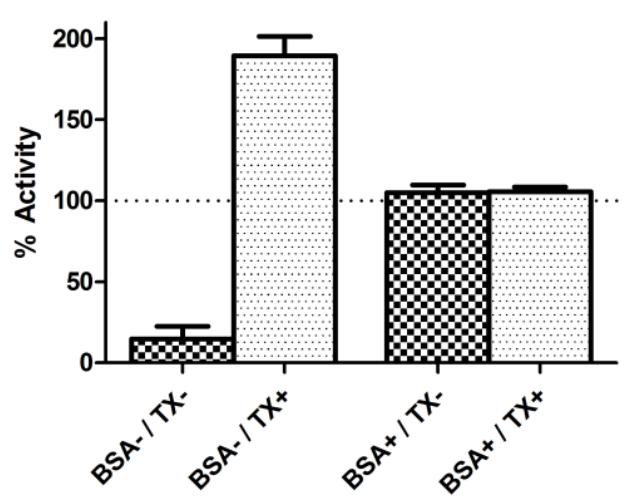

Figure S7. Effect of addition of BSA on SIRT1 activity modulation by $100 \mu \mathrm{M}$ of 2. Percent SIRT1 activity is calculated from activity under the same assay conditions in the absence of $\mathbf{2}$. TX-: absence of Triton X-100. TX+: presence of 0.01\% Triton X-100 (v:v). BSA-: absence of BSA. BSA+: presence of BSA $(1 \mathrm{mg} / \mathrm{mL})$. Error bars are SD from the mean of at least 3 experiments.

\section{SIRT1 assay with another enzyme source: from Enzo Life Sciences (BML-SE239)}

Enzyme stock nominal concentration: $0.031 \mathrm{mg} \cdot \mathrm{mL}^{-1}$ or $378 \mathrm{nM}$ (MW $\left.82 \mathrm{kDa}\right)$.

Assays were performed with addition of $1 \mu \mathrm{L}$ stock in a $50 \mu \mathrm{L}$ final volume. The final enzyme concentration was therefore approximately $8 \mathrm{nM}$. The enzyme stock solution contained $10 \%$ glycerol $\mathrm{v}: \mathrm{v}$, the final concentration of glycerol in the reaction mixture was $0.2 \%$.

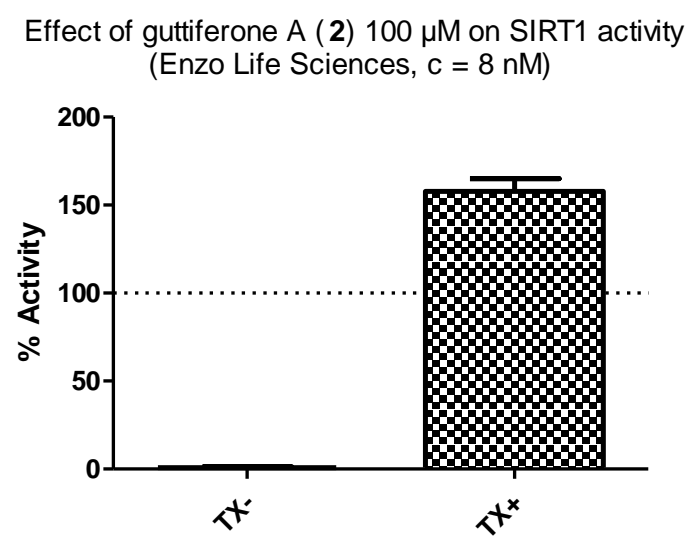

Figure S8. Percent SIRT1 activity in the presence of $100 \mu \mathrm{M}$ guttiferone A (2), compared to activity under the same assay conditions in the absence of 2 . Conditions for all experiments: [SIRT1] $=8 \mathrm{nM}$. TX-: absence of Triton X-100. TX+: presence of 0.01\% Triton X-100 (v:v). Error bars are SD from the mean of at least 3 experiments. 


\section{Trypsin activity assay results}

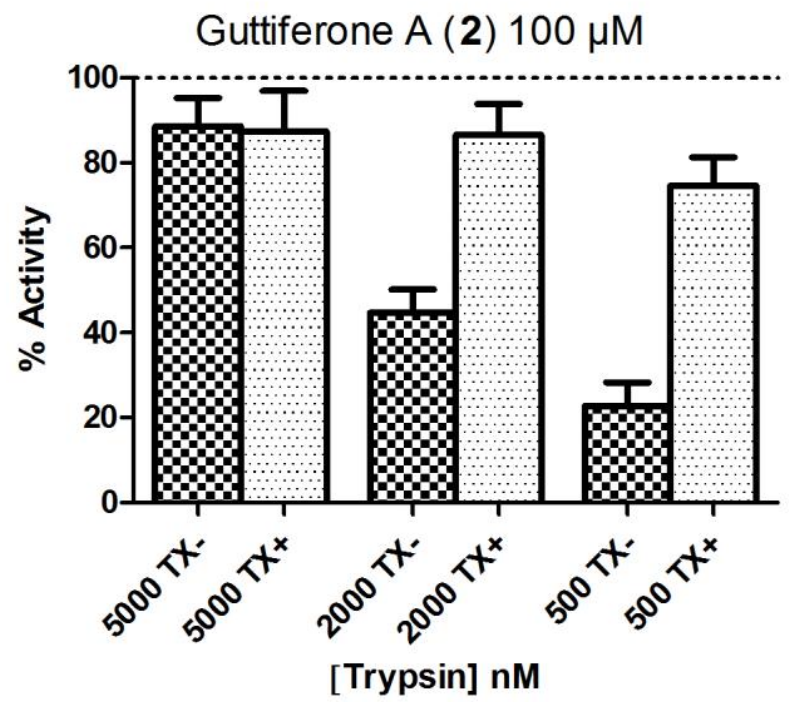

Figure S9. Percent trypsin activity in the presence of $100 \mu \mathrm{M}$ guttiferone $\mathrm{A}(\mathbf{2})$, compared to activity under the same assay conditions in the absence of $\mathbf{2}$, at the indicated trypsin concentration. TX-: absence of Triton X-100. TX+: presence of $0.01 \%$ Triton X-100 (v:v). Error bars are SD from the mean of at least 3 experiments. 


\section{Additional NMR spectra}

Guttiferone A (2)<smiles>CC(C)=CCC[C@]1(C)[C@H](CC=C(C)C)C[C@@]2(CC=C(C)C)C(O)=C(C(=O)c3ccc(O)c(O)c3)C(=O)[C@]1(CC=C(C)C)[C@@H]2CC=C(C)C</smiles>

$\mathrm{RMN}{ }^{1} \mathrm{H}(300 \mathrm{MHz}, \mathrm{MeOD}) \delta(\mathrm{ppm}): 7.19(\mathrm{~s}, 1 \mathrm{H}), 6.97(\mathrm{dd}, J=8.4$ and $2.2 \mathrm{~Hz}, 1 \mathrm{H}), 6.69(\mathrm{~d}, J=8.3$ $\mathrm{Hz}, 1 \mathrm{H}), 5.20$ (t, $J=7.0 \mathrm{~Hz}, 1 \mathrm{H}), 5.07$ (t, $J=7.0 \mathrm{~Hz}, 1 \mathrm{H}), 4.95(\mathrm{~m}, 1 \mathrm{H}), 4.89(\mathrm{~m}, 1 \mathrm{H}), 2.66(\mathrm{~m}, 2 \mathrm{H})$, $2.48(\mathrm{~m}, 2 \mathrm{H}), 2.11(\mathrm{~m}, 1 \mathrm{H}), 2.08(\mathrm{~m}, 2 \mathrm{H}), 2.01(\mathrm{~m}, 1 \mathrm{H}), 1.88(\mathrm{~m}, 2 \mathrm{H}), 1.84(\mathrm{~m}, 1 \mathrm{H}), 1.73(\mathrm{~s}, 3 \mathrm{H}), 1.69$ (s, 3H), $1.68(\mathrm{~s}, 9 \mathrm{H}), 1.66(\mathrm{~s}, 3 \mathrm{H}), 1.60(\mathrm{~s}, 3 \mathrm{H}), 1.47(\mathrm{~s}, 3 \mathrm{H}), 1.41(\mathrm{~m}, 1 \mathrm{H}), 1.25(\mathrm{~s}, 3 \mathrm{H}), 1.22(\mathrm{~m}, 1 \mathrm{H})$.

$\mathrm{RMN}{ }^{13} \mathrm{C}$ (75 MHz, MeOD) $\delta(\mathrm{ppm}): 209.5,195.5,195.4,195.1,152.5,146.1,135.7,135.7,133.7$, 132.8, 129.3, 125.4, 125.1, 125.0, 120.8, 120.7, 117.7, 117.3, 115.1, 68.8, 62.1, 51.9, 41.1, 40.1, 36.9, 32.0, 29.8, 26.6, 26.3, 26.3, 25.1, 26.0, 23.7, 19.7, 18.3, 18.2, 18.1, 17.7. 


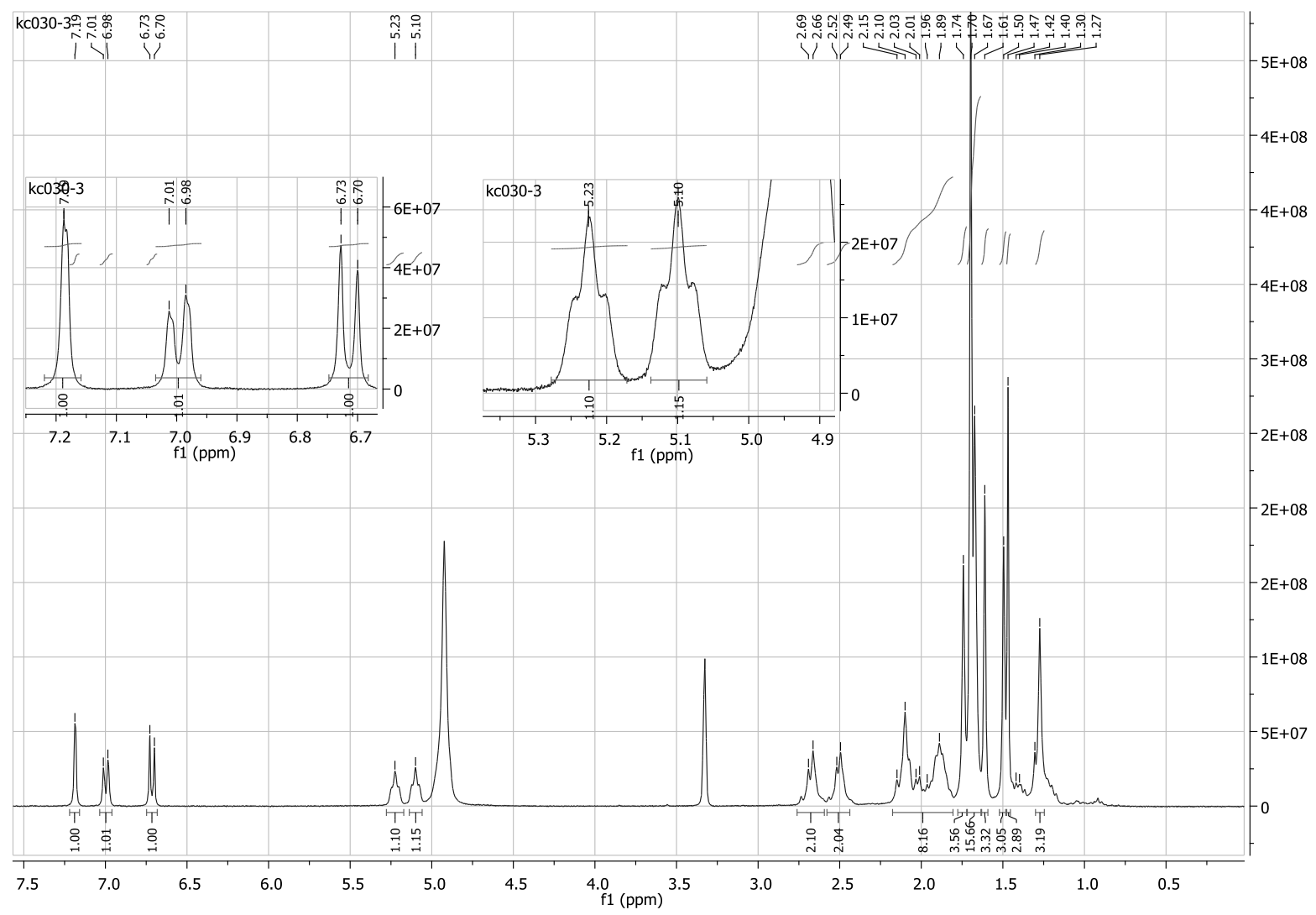

Figure S10. ${ }^{1} \mathrm{H}$ NMR spectrum of guttiferone A 2.

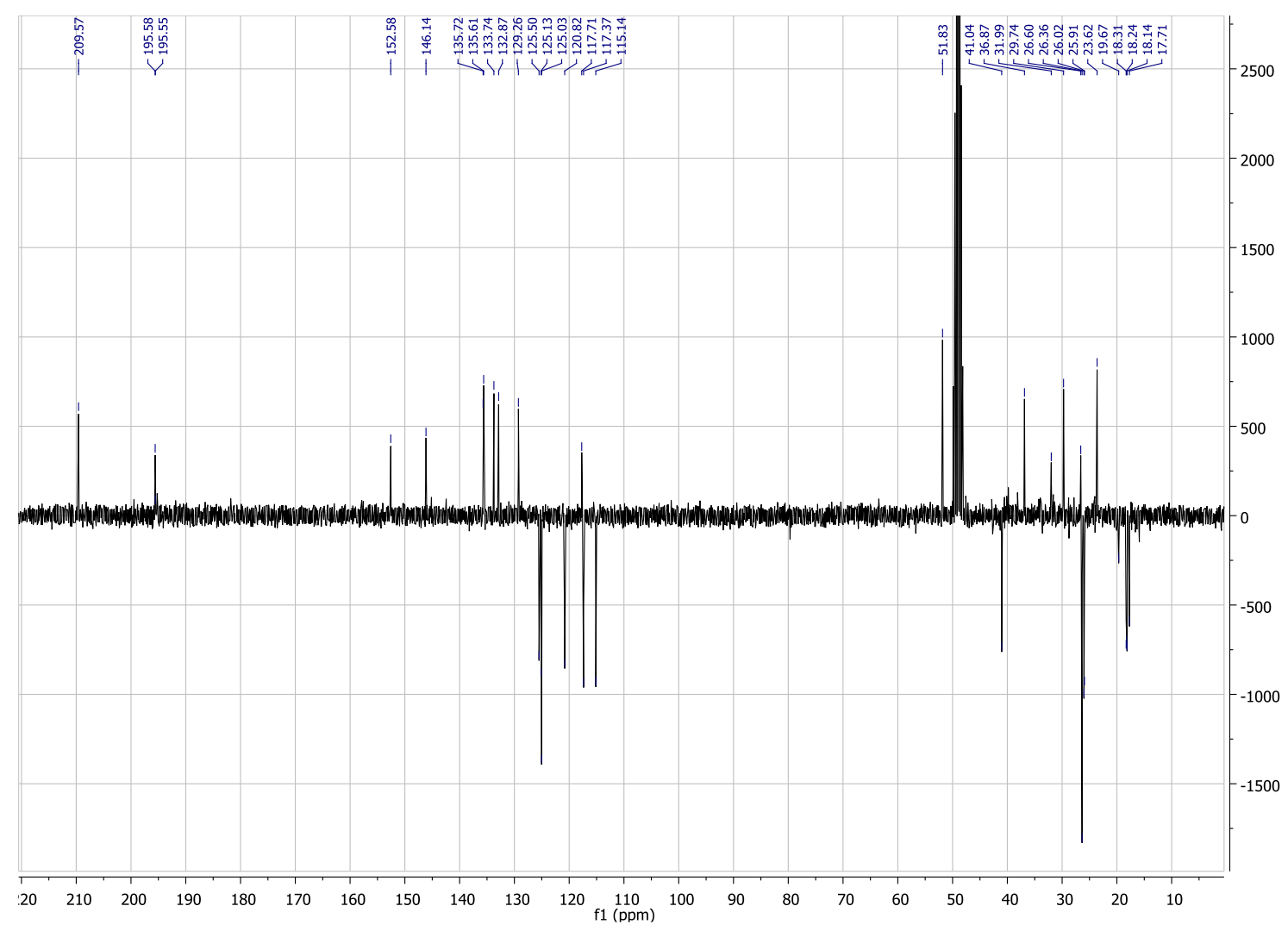

Figure S11. ${ }^{13} \mathrm{C}$ NMR spectrum of guttiferone A 2 . 
Hyperforin (3)

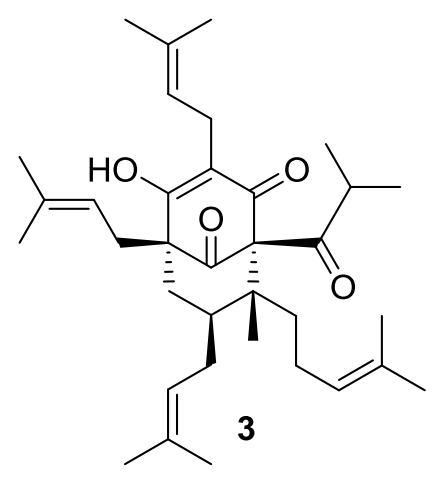

$\mathrm{RMN}{ }^{1} \mathrm{H}\left(300 \mathrm{MHz}, \mathrm{CD}_{3} \mathrm{OD}\right) \delta(\mathrm{ppm}): 5.10(\mathrm{t}, J=5.6 \mathrm{~Hz}, 1 \mathrm{H}), 5.01(\mathrm{~m}, 1 \mathrm{H}), 4.99(\mathrm{~m}, 1 \mathrm{H}), 4.96(\mathrm{~m}$, $1 \mathrm{H}), 3.14(\mathrm{~m}, 1 \mathrm{H}), 3.09(\mathrm{~m}, 1 \mathrm{H}), 2.51(\mathrm{dd}, J=13.3$ and $6.0 \mathrm{~Hz}, 1 \mathrm{H}), 2.41(\mathrm{dd}, J=13.3$ and $6.0 \mathrm{~Hz}$, 1H), $2.10(\mathrm{~m}, 1 \mathrm{H}), 2.06(\mathrm{~m}, 1 \mathrm{H}), 1.97(\mathrm{~m}, 1 \mathrm{H}), 1.91(\mathrm{~m}, 3 \mathrm{H}), 1.74(\mathrm{~m}, 2 \mathrm{H}), 1.73(\mathrm{~m}, 1 \mathrm{H}), 1.71(\mathrm{~s}, 3 \mathrm{H})$, $1.69(\mathrm{~s}, 6 \mathrm{H}), 1.68(\mathrm{~m}, 2 \mathrm{H}), 1.66(\mathrm{~s}, 3 \mathrm{H}), 1.64(\mathrm{~s}, 3 \mathrm{H}), 1.63(\mathrm{~s}, 3 \mathrm{H}), 1.59(\mathrm{~s}, 3 \mathrm{H}), 1.58(\mathrm{~s}, 3 \mathrm{H}), 1.09$ (d, $J$ $=6.3 \mathrm{~Hz}, 3 \mathrm{H}), 1.03(\mathrm{~d}, J=6.3 \mathrm{~Hz}, 3 \mathrm{H}), 0.98(\mathrm{~s}, 3 \mathrm{H})$.

RMN ${ }^{13} \mathrm{C}$ Jmod (75 MHz, CD $\left.{ }_{3} \mathrm{OD}\right) \delta(\mathrm{ppm}): 211.7,208.8,195.3,194.8,134.7,134.2,133.6,131.8$, 126.1, 123.7, 122.5, 122.1, 120.9, 82.7, 59.9, 49.5, 43.1, 43.0, 40.8, 37.9, 30.7, 28.6, 26.20, 26.0, 26.0, $25.9,25.4,22.5,22.0,20.9,18.3,18.2,18.1,17.8,15.3$. 
Supporting Information

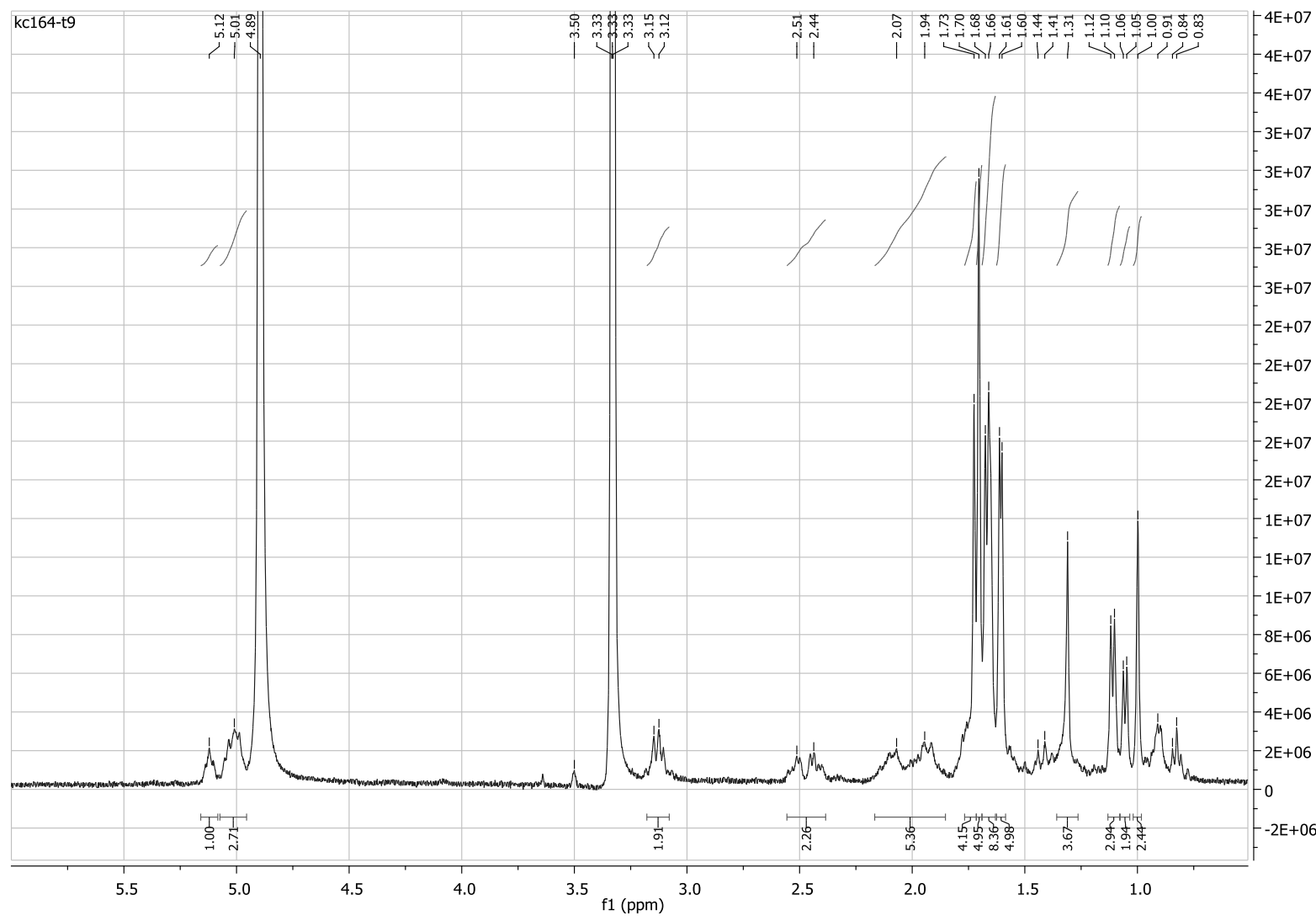

Figure S12. ${ }^{1} \mathrm{H}$ NMR spectrum of hyperforin 3 .

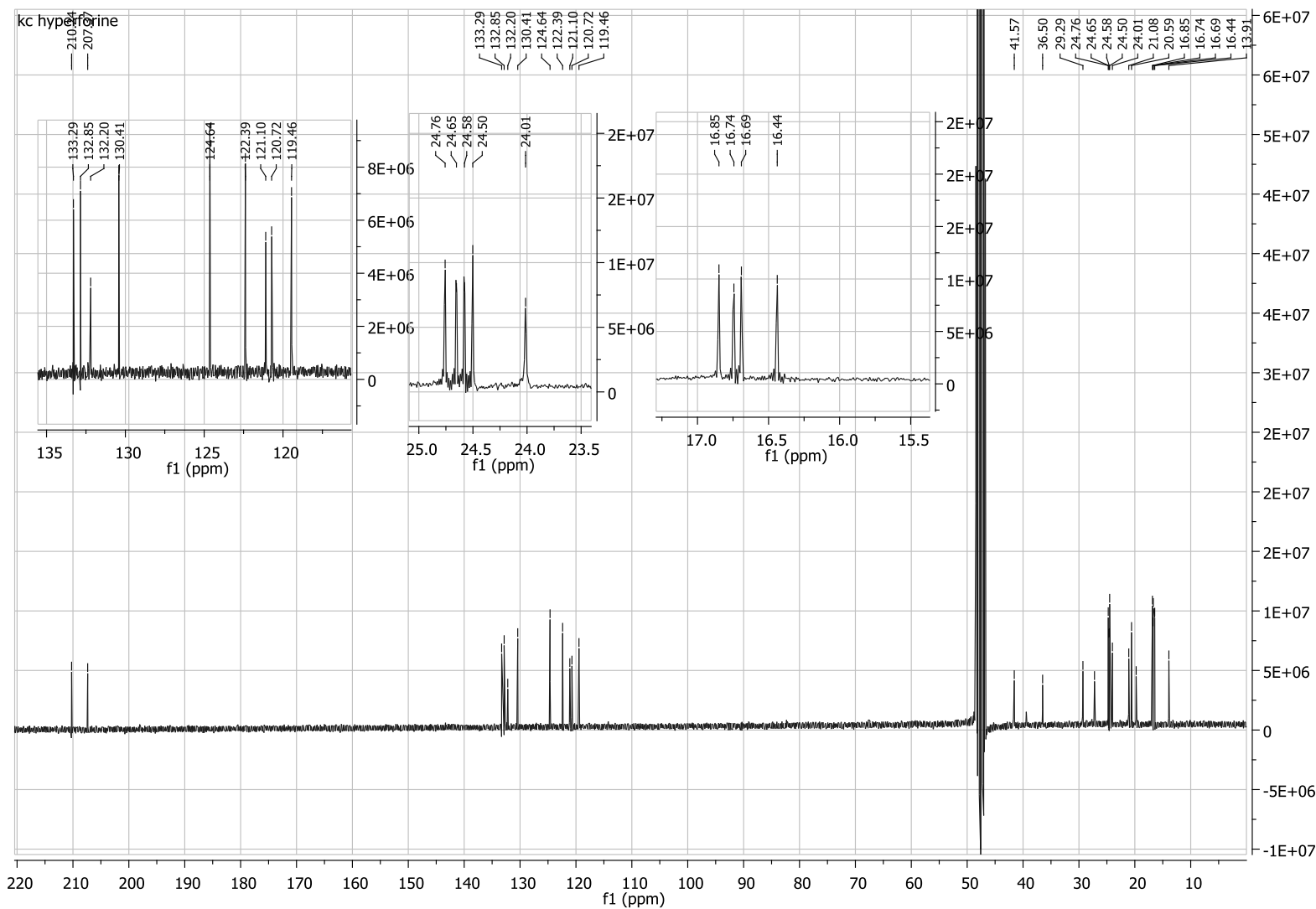

Figure S13. ${ }^{13} \mathrm{C}$ NMR spectrum of hyperforin 3 . 
Aristoforin (4)

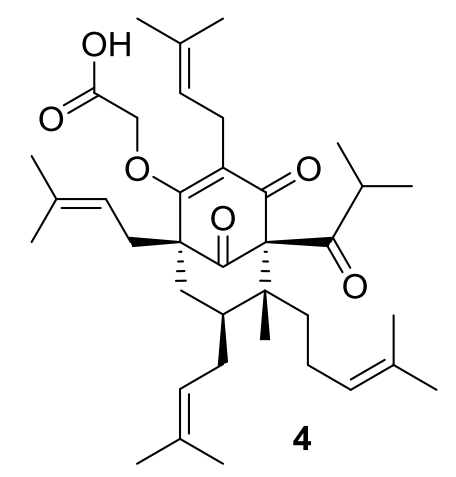

${ }^{1} \mathrm{H}$ NMR (300 MHz, $\left.\mathrm{CDCl}_{3}\right) \delta(\mathrm{ppm}): 5.07(\mathrm{~m}, 3 \mathrm{H}), 4.99(\mathrm{~m}, 1 \mathrm{H}), 4.69(\mathrm{dd}, J=16.0$ and $8.1 \mathrm{~Hz}, 1 \mathrm{H})$, $3.18(\mathrm{~m}, 2 \mathrm{H}), 2.62(\mathrm{~d}, J=8.1 \mathrm{~Hz}, 2 \mathrm{H}), 2.10(\mathrm{~m}, 4 \mathrm{H}), 1.93(\mathrm{~m}, 1 \mathrm{H}), 1.79(\mathrm{~m}, 1 \mathrm{H}), 1.71(\mathrm{~s}, 6 \mathrm{H}), 1.72(\mathrm{~s}$, 9H), $1.69(\mathrm{~m}, 2 \mathrm{H}), 1.64(\mathrm{~s}, 3 \mathrm{H}), 1.60(\mathrm{~s}, 3 \mathrm{H}), 1.52(\mathrm{~m}, 1 \mathrm{H}), 1.35(\mathrm{~m}, 1 \mathrm{H}), 1.16(\mathrm{~d}, J=16.5 \mathrm{~Hz}, 3 \mathrm{H})$, $1.06(\mathrm{~d}, J=6.5 \mathrm{~Hz}, 3 \mathrm{H}), 1.1(\mathrm{~s}, 3 \mathrm{H})$.

${ }^{13} \mathrm{C}$ NMR $\left(75 \mathrm{MHz}, \mathrm{CDCl}_{3}\right) \delta(\mathrm{ppm}): 208.8,206.8,190.0,172.4,170.5,134.5,134.1,133.6,131.3$, 128.3, 124.6, 122.6, 120.9, 199.4, 84.3, 70.1, 59.0, 51.5, 49.5, 43.6, 42.90, 38.4, 36.5, 29.9, 27.0, 25.9, $25.8,25.7,25.6,25.0,23.7,21.3,20.4,18.1,18.0,17.9,17.7$ 


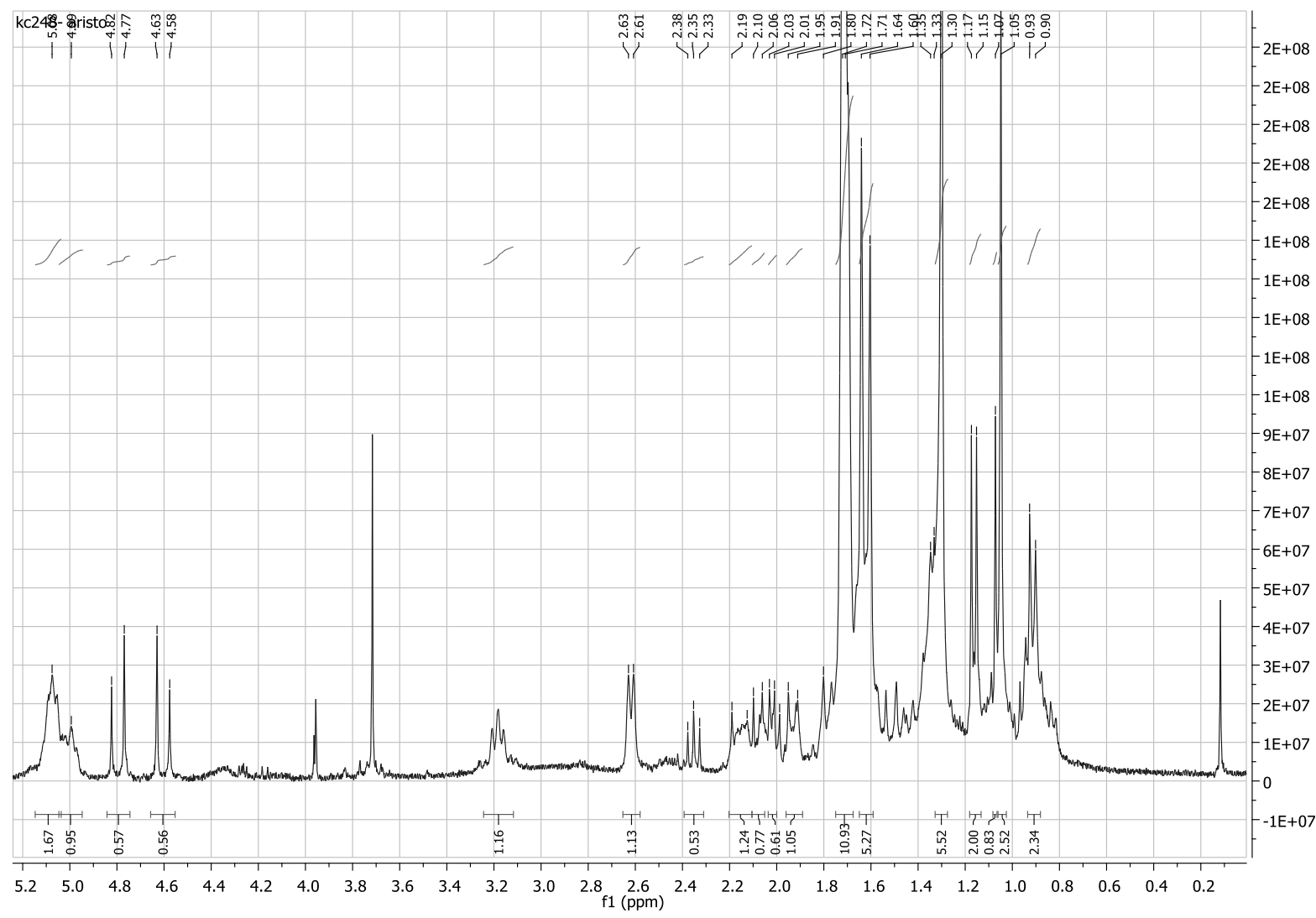

Figure S14. ${ }^{1} \mathrm{H}$ NMR spectrum of aristoforin 4.

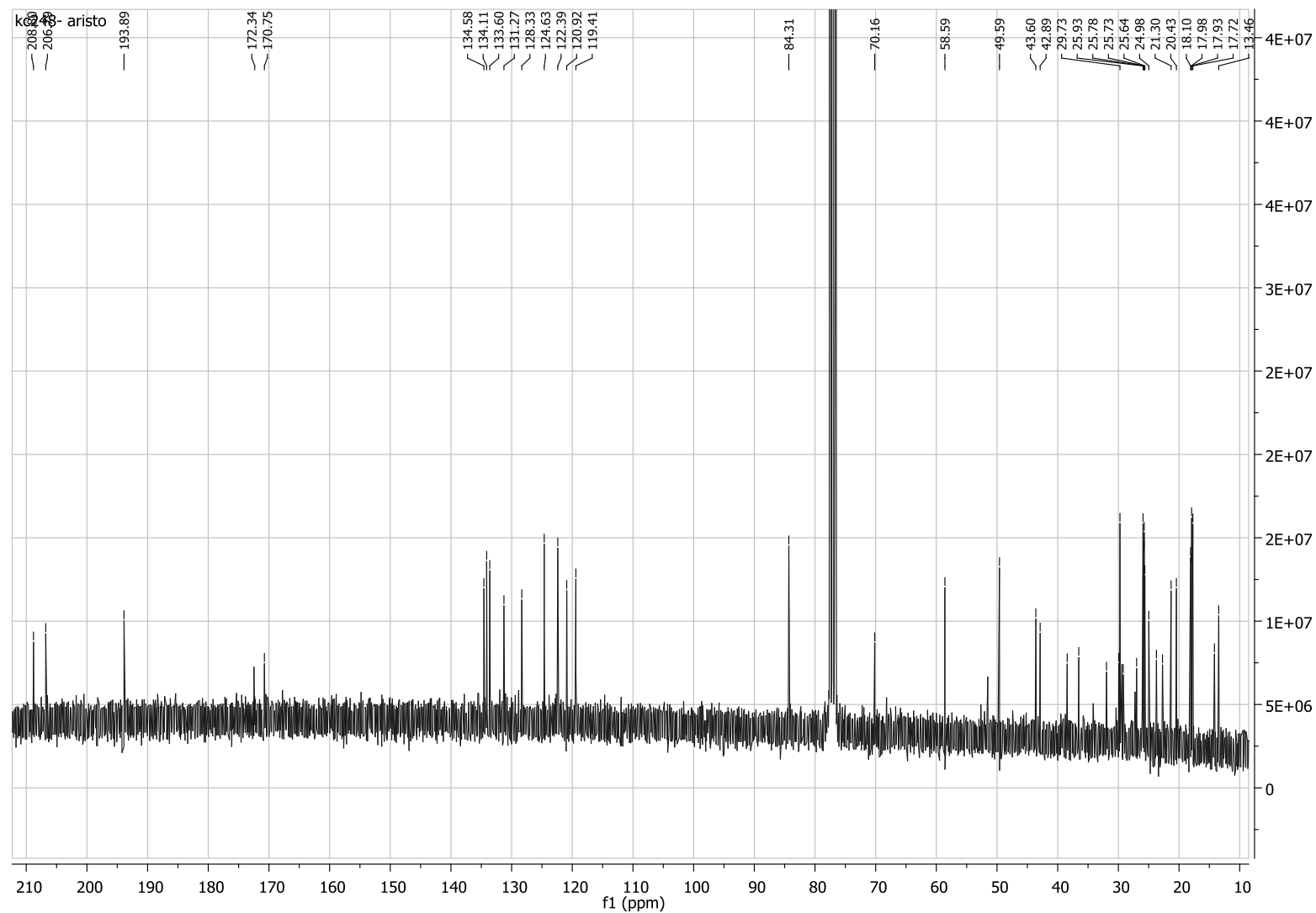

Figure S15. ${ }^{13} \mathrm{C}$ NMR spectrum of aristoforin 4 . 


\section{NMR Assay}
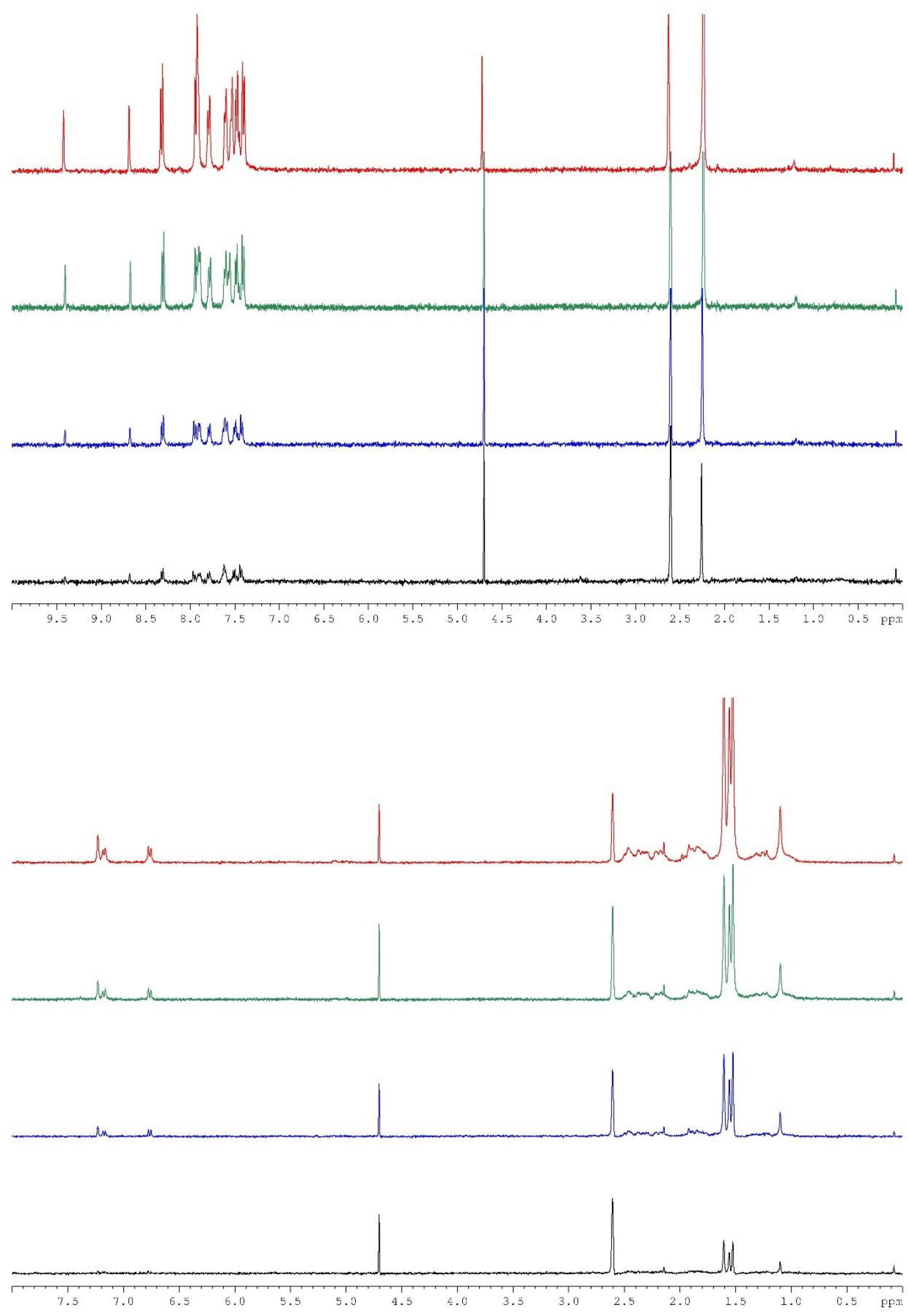

Figure S16. NMR assay of suramin (top) and 2 (bottom). ${ }^{1} \mathrm{H}$ NMR spectra (400 MHz) were recorded in deuterated phosphate buffer $(50 \mathrm{mM}, \mathrm{pH} 8.0)$ with $1 \% d 6$-DMSO at the following concentrations: $200 \mu \mathrm{M}$ (red), $100 \mu \mathrm{M}$ (green), $50 \mu \mathrm{M}$ (blue) and $25 \mu \mathrm{M}$ (black). 


\section{Aggregation of guttiferone A (2) induced by Triton X-100}
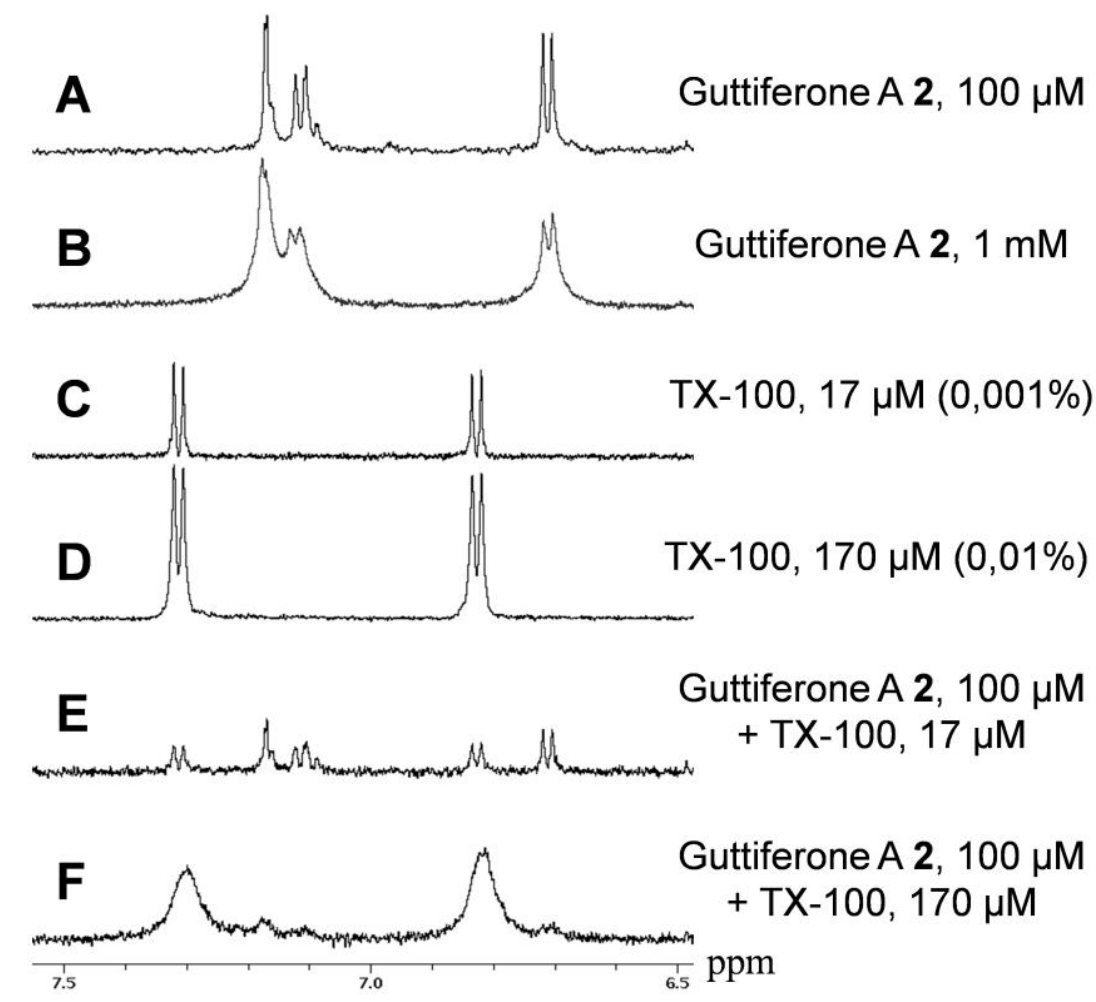

Figure S17. Aromatic region of ${ }^{1} \mathrm{H}$ NMR (600 MHz) of guttiferone A (2) with or without TX-100, as indicated. NMR spectra were recorded in deuterated phosphate buffer $(50 \mathrm{mM}, \mathrm{pH} 8.0)$ with $1 \%$ d6DMSO.

\section{Additional discussion (figure S17)}

- Guttiferone A (2) at $100 \mu \mathrm{M}$ did not aggregate significantly. Resonances were sharp and splitting of the peaks was observable on the spectra (A). 2 at $1 \mathrm{mM}$ exhibited a very large line broadening of the peaks, demonstrating that at this concentration 2 aggregated even without detergent TX-100 (B). Moreover, a small chemical shift variation of the aromatic resonance around $7.15 \mathrm{ppm}$ occurred (comparing A and B).

- TX-100 at the concentration of $17 \mu \mathrm{M}(0.001 \% \mathrm{v}: \mathrm{v})$ showed very well resolved resonances, demonstrating that it did not aggregate (C). At the concentration of $170 \mu \mathrm{M}(0.01 \% \mathrm{v}: \mathrm{v})$, a small broadening of the resonances was observed, showing that it started to aggregate (D).

- The addition of TX-100 $(17 \mu \mathrm{M})$ to a solution of $2(100 \mu \mathrm{M})$ resulted in a decrease of the intensities of the resonances of $\mathbf{2}$ as well as those of TX-100, but no broadening of the peaks was apparent (E). This result showed that TX-100 interacted with $\mathbf{2}$ and slightly aggregated it at this concentration. We did not observe the apparition of new resonances or any shift of the resonances. This interaction did not seem very strong and the observed decrease of the peak intensities could correspond to an 
intermediate exchange between the free and the bound molecules combined with slight aggregation (E).

The addition of TX-100 $(170 \mu \mathrm{M})$ to a solution of $2(100 \mu \mathrm{M})$ resulted in a very important line broadening of the resonances of both 2 and TX-100 (F). Resonances corresponding to 2 almost vanished due to the large line width. Moreover, a slight chemical shift variation of the resonances corresponding to TX-100 was observed at $7.3 \mathrm{ppm}(\mathrm{F})$. These results showed that TX-100 interacted with 2 , provoked its aggregation and that the two molecules co-aggregated.

\section{Line width evaluation of guttiferone A (2) resonances}

Due to the high aggregation phenomenon of guttiferone A (2) in the presence of $0.01 \%$ TX-100, the measure of the line width of resonances was difficult to perform. We decided to measure the line width of the resonance at $7.152 \mathrm{ppm}$ corresponding to one of the aromatic protons of $\mathbf{2}$. The line width at half height for 2 at $100 \mu \mathrm{M}$ and $1 \mathrm{mM}$ without TX-100 and for 2 at $100 \mu \mathrm{M}$ in the presence of TX100 at $17 \mu \mathrm{M}$ and $170 \mu \mathrm{M}$ are given in table S1.

\begin{tabular}{|c|c|}
\hline & Resonance line width $\mathbf{( H z )}$ \\
\hline Guttiferone A 2 $(\mathbf{1 0 0} \boldsymbol{\mu M})$ & 4.70 \\
\hline Guttiferone A 2 $(\mathbf{1} \mathbf{~ m M})$ & 16.25 \\
\hline $\begin{array}{c}\text { Guttiferone A 2 }(\mathbf{1 0 0} \boldsymbol{\mu M}) \\
+ \text { TX100 }(\mathbf{0 . 0 0 1} \%, \mathbf{1 7} \boldsymbol{\mu M})\end{array}$ \\
\hline $\begin{array}{c}\text { Guttiferone A 2 (100 } \boldsymbol{\mu M}) \\
+ \text { TX100 }(\mathbf{0 . 0 1} \%, \mathbf{1 7 0} \boldsymbol{\mu M})\end{array}$ \\
\hline
\end{tabular}

Table S1. Line width evaluation of guttiferone A (2) resonances. The resonance at $7.152 \mathrm{ppm}$ was chosen. 


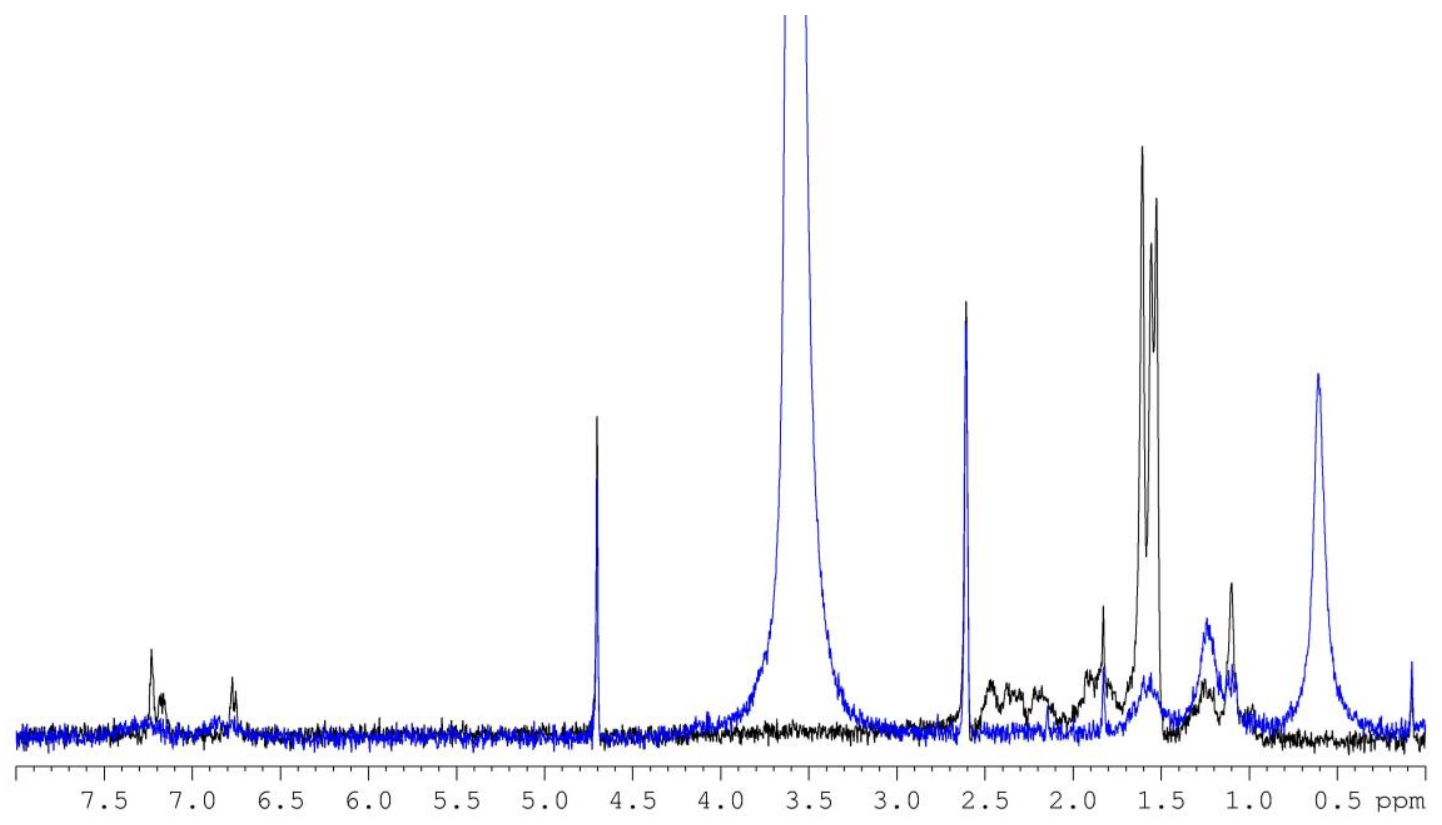

Figure S18. ${ }^{1} \mathrm{H}$ NMR spectra of $100 \mu \mathrm{M}$ of guttiferone A (2) without (black) and with (blue) $0.01 \%$ TX-100 (1000 scans, see the experimental section for details).

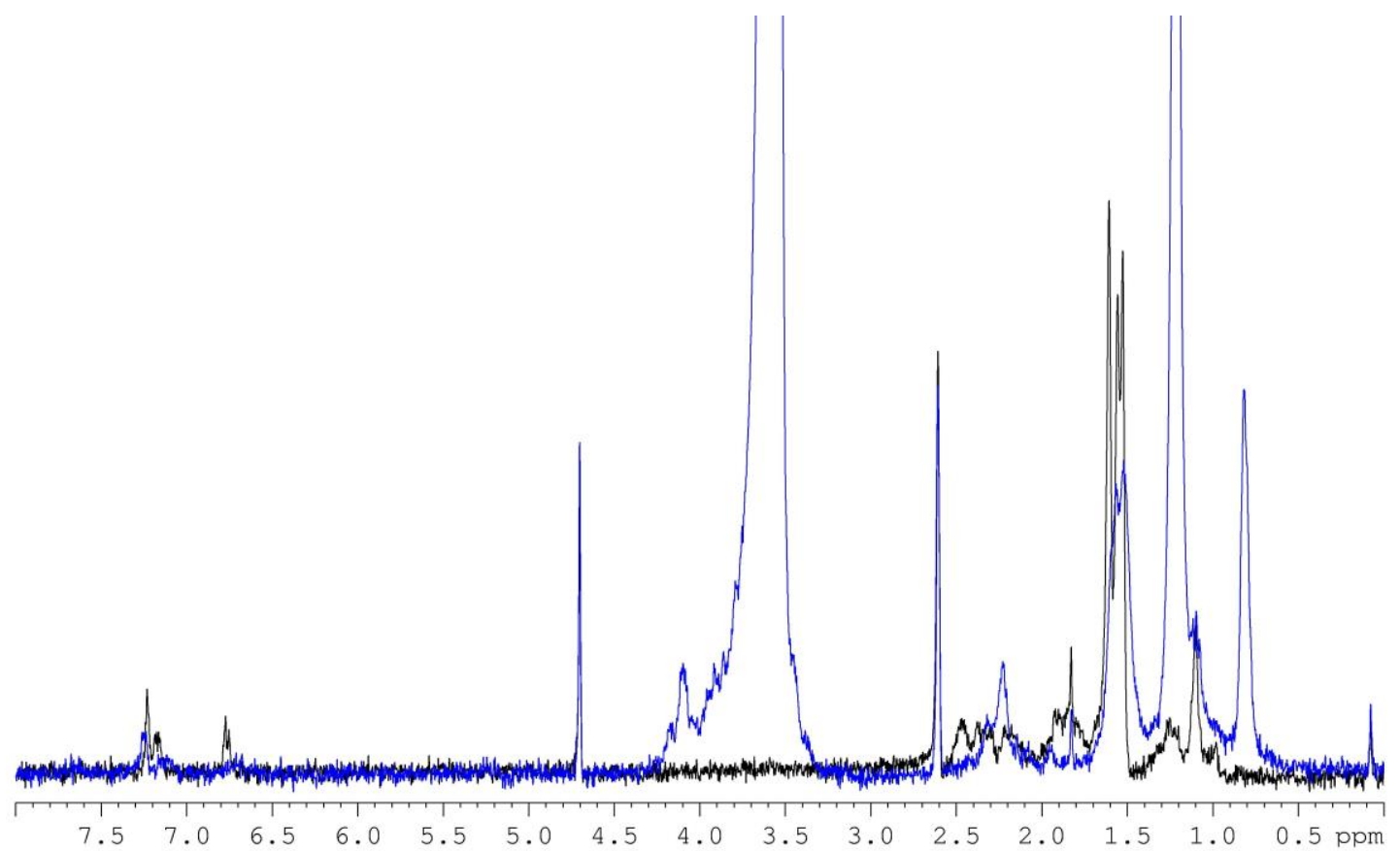

Figure S19. ${ }^{1} \mathrm{H}$ NMR spectra of $100 \mu \mathrm{M}$ of guttiferone A (2) without (black) and with (blue) $0.01 \%$ Tween ${ }^{\circledR} 20$ (1000 scans, see the experimental section for details). 


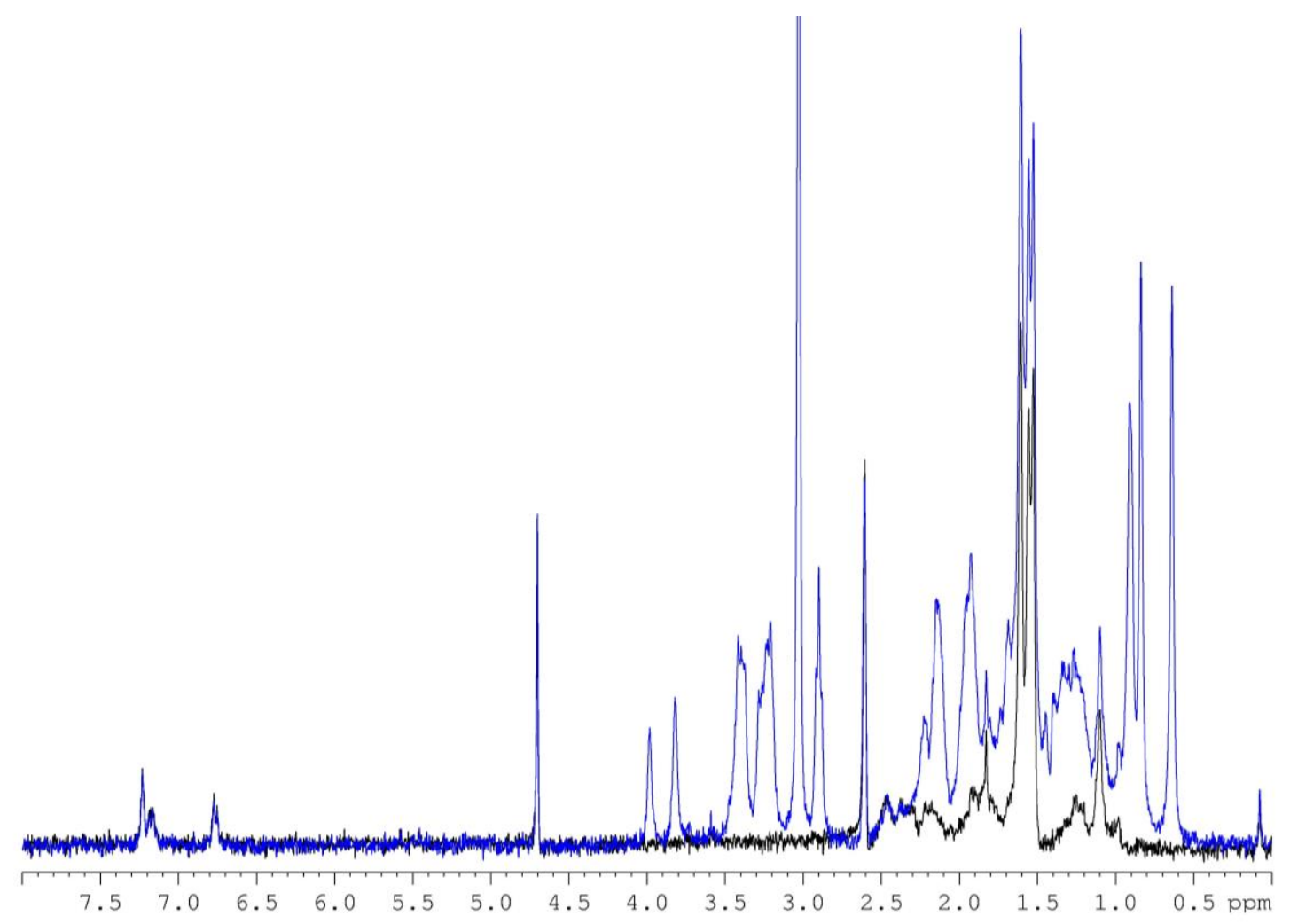

Figure S20. ${ }^{1} \mathrm{H}$ NMR spectra of $100 \mu \mathrm{M}$ of guttiferone A (2) without (black) and with (blue) $0.01 \%$ CHAPS (1000 scans, see the experimental section for details).

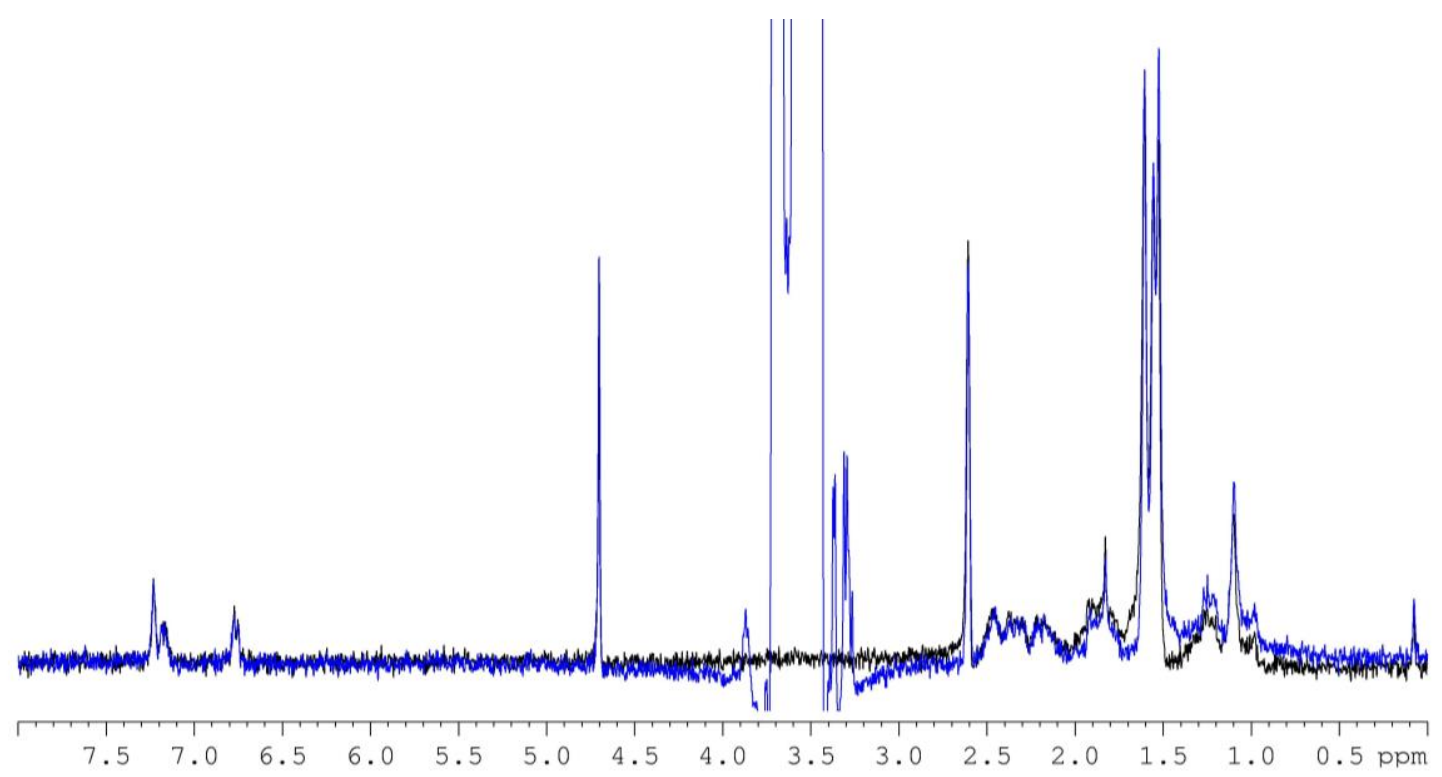

Figure S21. ${ }^{1} \mathrm{H}$ NMR spectra of $100 \mu \mathrm{M}$ of guttiferone A (2) without (black) and with (blue) $0.2 \%$ glycerol (1000 scans, see the experimental section for details). 

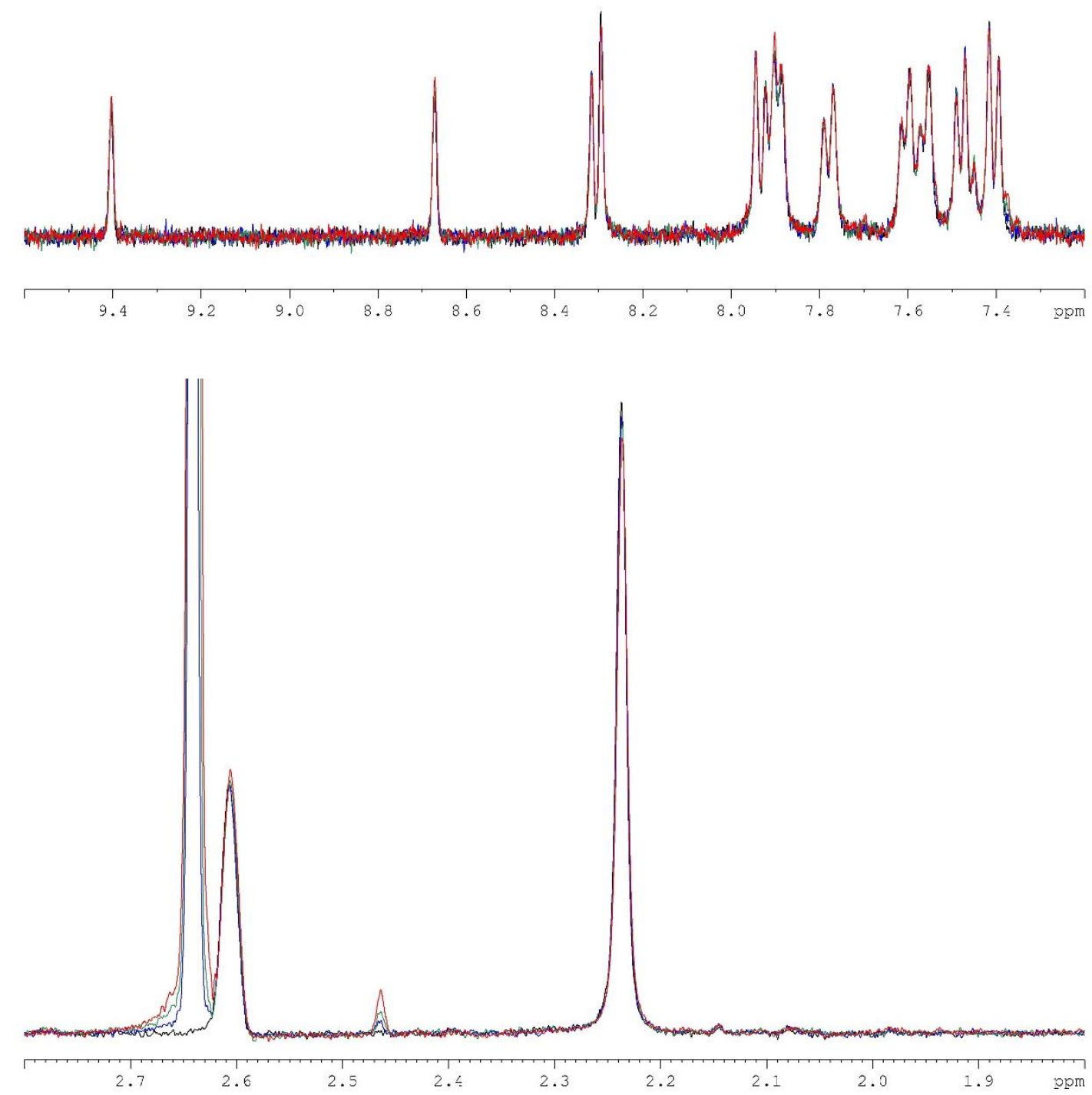

Figure S22. Aromatic (top) and aliphatic (bottom) regions of NMR spectra of $100 \mu \mathrm{M}$ of suramin without SIRT1 (black) and with $25 \mathrm{nM}$ (blue), $50 \mathrm{nM}$ (green) and $100 \mathrm{nM}$ (red) SIRT1. 

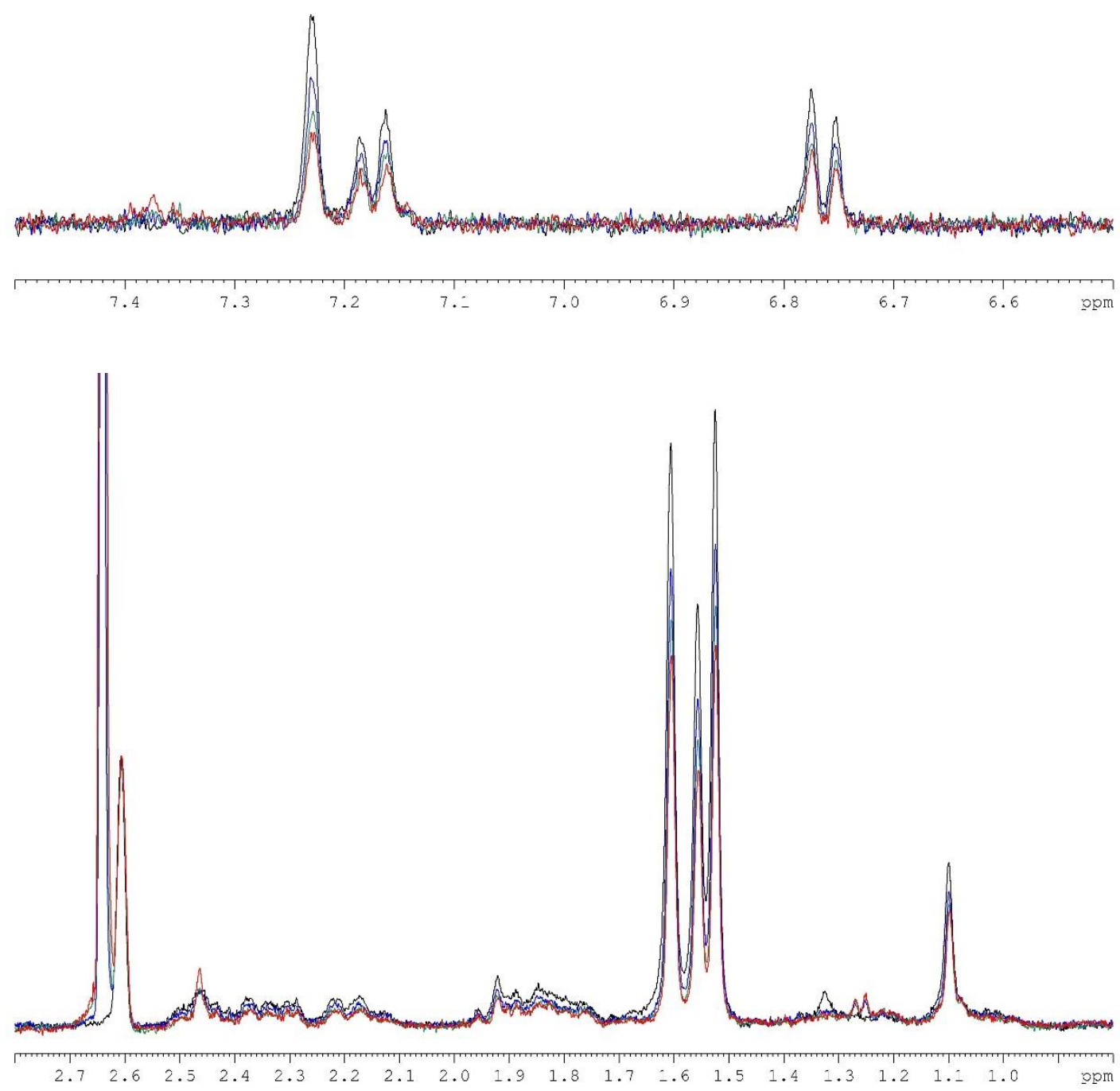

Figure S23. Aromatic (top) and aliphatic (bottom) regions of NMR spectra of $100 \mu \mathrm{M}$ of 2 without SIRT1 (black) and with $25 \mathrm{nM}$ (blue), $50 \mathrm{nM}$ (green) and $100 \mathrm{nM}$ (red) SIRT1. 


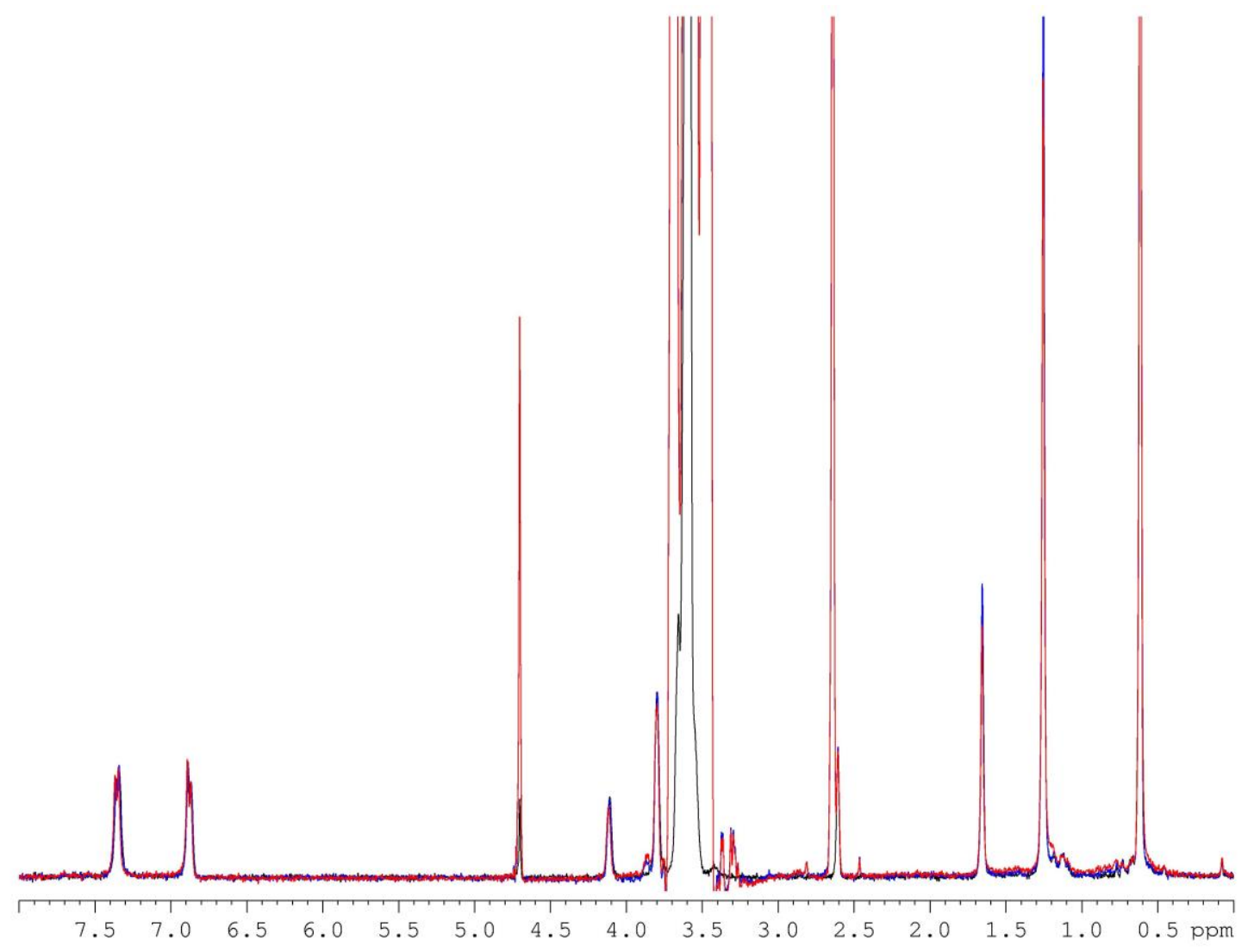

Figure S24. ${ }^{1} \mathrm{H}$ NMR spectra of $0.01 \%$ TX-100 alone (black), and with addition of $100 \mathrm{nM}$ SIRT1 (blue) followed by $1.5 \mu \mathrm{M}$ BSA $(0.1 \mathrm{mg} / \mathrm{mL}$, red). The intense signals between 3.5 and $3.7 \mathrm{ppm}$ are due to the presence of glycerol in the stock solution of SIRT1. 1000 scans, see the experimental section for details. 
Supporting Information

Diffusion-ordered spectroscopy (2D DOSY) NMR

\begin{tabular}{lcc}
\hline & $\begin{array}{c}\text { Diffusion } \\
\text { coefficient } \\
\mathbf{1 0}^{-10}\left(\mathbf{m}^{2} / \mathbf{s}\right)\end{array}$ & Log $\mathbf{1 0}^{\text {diffusion coefficient }}$ \\
\hline $\mathbf{2}(\mathbf{1 0 0} \boldsymbol{\mu M})$ & 2.706 & -9.568 \\
\hline $\mathbf{2}(\mathbf{1} \mathbf{~ m M})$ & 2.246 & -9.649 \\
\hline $\mathbf{2}(\mathbf{1 0 0} \boldsymbol{\mu M})$ & 2.298 & -9.639 \\
$+\mathbf{T X}-\mathbf{1 0 0}(\mathbf{0 . 0 0 1 \% )}$ & 1.808 & -9.740 \\
\hline $\mathbf{2}(\mathbf{1 0 0} \boldsymbol{\mu M})$ & 2.606 & -9.584 \\
$+\mathbf{T X}-\mathbf{1 0 0}(\mathbf{0 . 0 1 \%})$ & 1.610 & -9.793 \\
\hline $\mathbf{2}(\mathbf{1 0 0} \boldsymbol{\mu M})^{\mathbf{a}}$ & & \\
\hline $\mathbf{2}(\mathbf{1 0 0} \boldsymbol{\mu M})$ & & \\
\hline $\mathbf{H S A}(\mathbf{1 . 5} \boldsymbol{\mu M})^{\mathrm{a}}$ & & \\
\hline
\end{tabular}

Table S2. Diffusion coefficients measured by 2D DOSY NMR for guttiferone A (2). See the experimental section for details.

${ }^{\text {a }}$ DOSY experiments have been performed on a different $600 \mathrm{MHz}$ spectrometer and coefficient diffusion values for $2(100 \mu \mathrm{M})$ and $2(100 \mu \mathrm{M})+$ BSA $(1.5 \mu \mathrm{M})$ have been corrected for spectrometer change using the diffusion coefficients measured from DMSO. Values have been recalculated according to the equation: $\mathrm{D}_{\text {corrected }}=\mathrm{D}_{\text {raw }} * \mathrm{DMSO}_{\text {ref }} / \mathrm{DMSO}_{\text {raw }}$, where $\mathrm{D}_{\text {corrected }}$ is the recalculated value, $\mathrm{D}_{\text {raw }}$ is the original value, $\mathrm{DMSO}_{\text {ref }}$ and $\mathrm{DMSO}_{\text {raw }}$ are respectively the two reference values for DMSO. 


\section{Diffusion-ordered spectroscopy (2D DOSY) NMR}

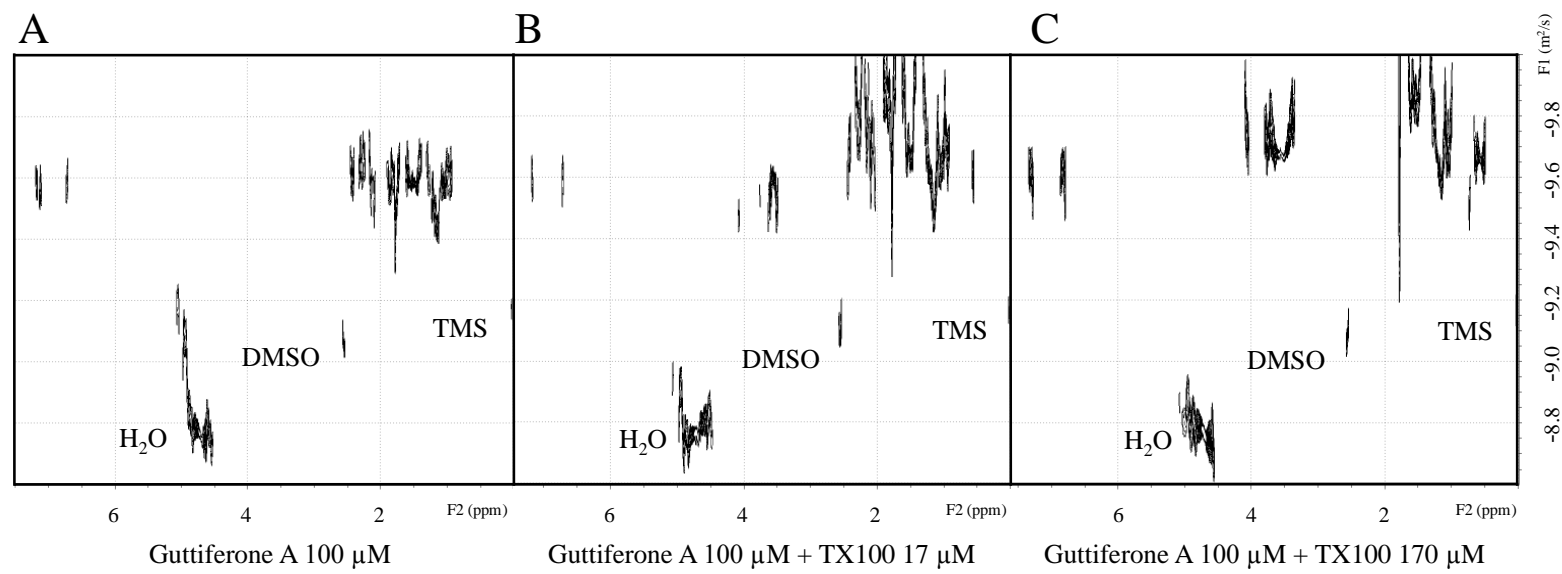

Figure S25. 2D DOSY NMR experiments of guttiferone A (2) without (A) or with TX-100 $17 \mu \mathrm{M}$ (B) and $170 \mu \mathrm{M}(\mathrm{C})$. Experiments were performed on a $600 \mathrm{MHz}$ spectrometer equipped with a cryoprobe (see the experimental section for details).

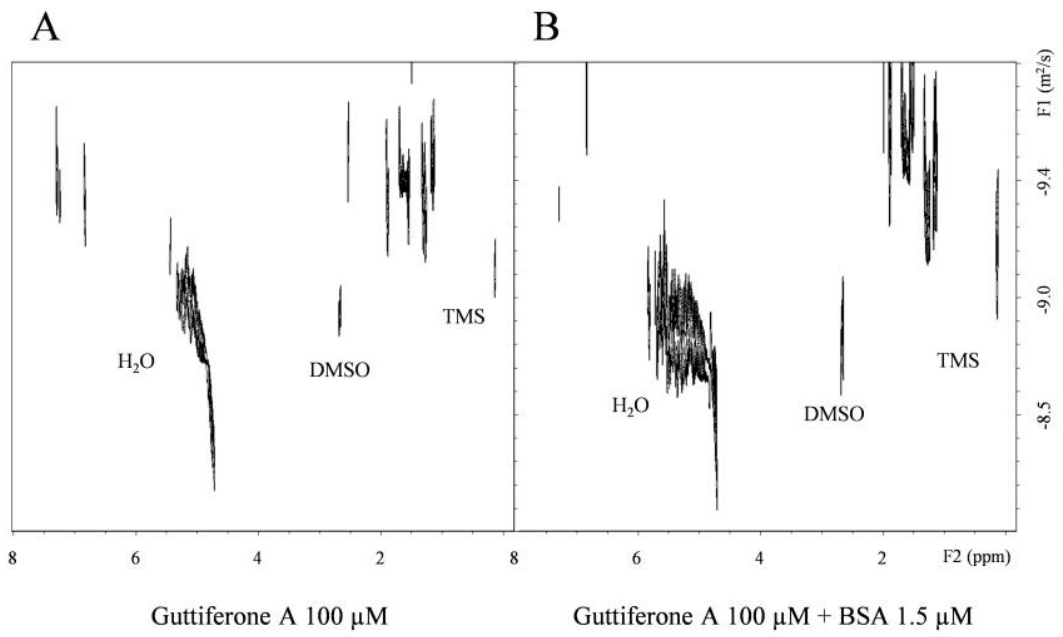

Figure S26. 2D DOSY NMR experiments of guttiferone A (2) without (A) or with 1.5 $\mu$ M BSA (B). Experiments were performed on a $600 \mathrm{MHz}$ spectrometer (see the experimental section for details). 


\section{DLS results}

\begin{tabular}{|c|c|c|c|}
\hline Conditions & $\mathbf{P d} \mathbf{I}^{\mathbf{a}}$ & $\mathbf{k c p s}^{\mathrm{b}}$ & Size $(\mathbf{n m})^{\mathrm{c}}$ \\
\hline TX-100 (0.01\%) & 1.000 & 11.8 & \\
\hline $2(100 \mu M)$ & 0.456 & 18.3 & \\
\hline $2(100 \mu \mathrm{M})+\mathrm{TX}-100(0.01 \%)$ & 0.206 & 165.3 & 119.7 \\
\hline BSA (15 $\mu \mathrm{M})$ & 0.361 & 13.5 & \\
\hline $2(100 \mu \mathrm{M})+\mathrm{BSA}(15 \mu \mathrm{M})$ & 0.717 & 32.2 & \\
\hline SIRT1 (250 nM) & 1.000 & 9.3 & \\
\hline $2(100 \mu M)+\operatorname{SIRT1}(250 \mathrm{nM})$ & 0.333 & 29.1 & \\
\hline
\end{tabular}

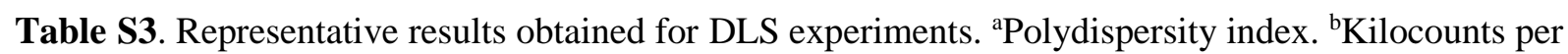
second. ${ }^{c}$ Estimated size of the particles (given only in the case where the PdI is $<0.3$ and the count number is $>100 \mathrm{kcps}$ to avoid over-interpretation of the data). See the experimental section for details.

\section{Autocorrelation curves}

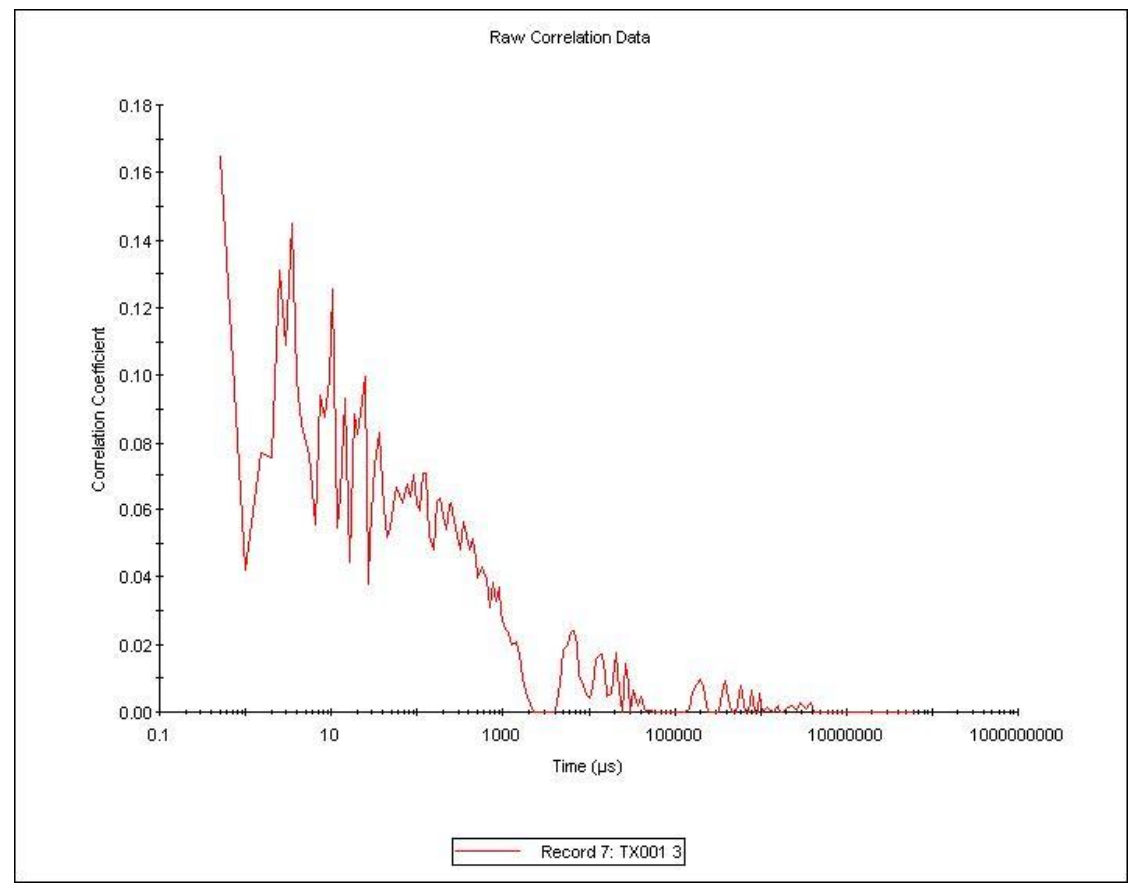

TX-100 (0.01\%) 
Supporting Information

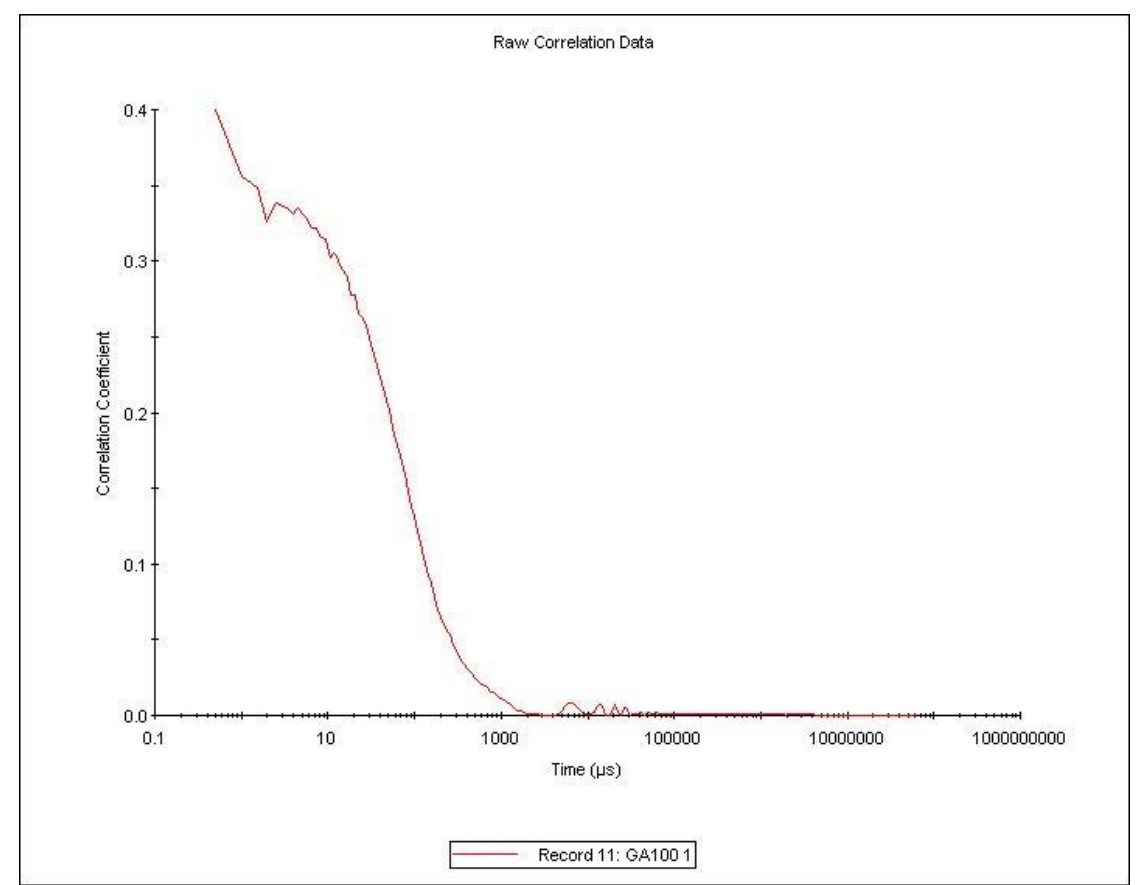

$2(100 \mu \mathrm{M})$

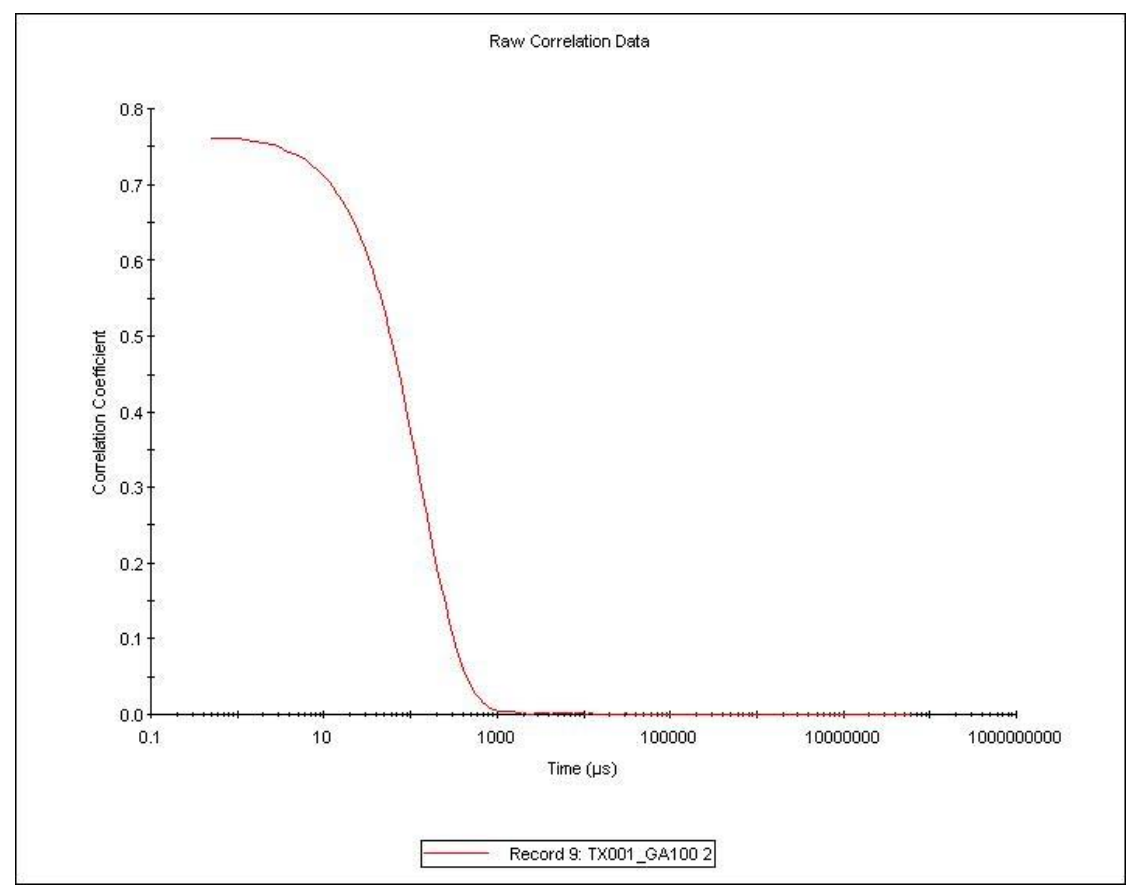

$2(100 \mu \mathrm{M})+\mathrm{TX}-100(0.01 \%)$ 
Supporting Information

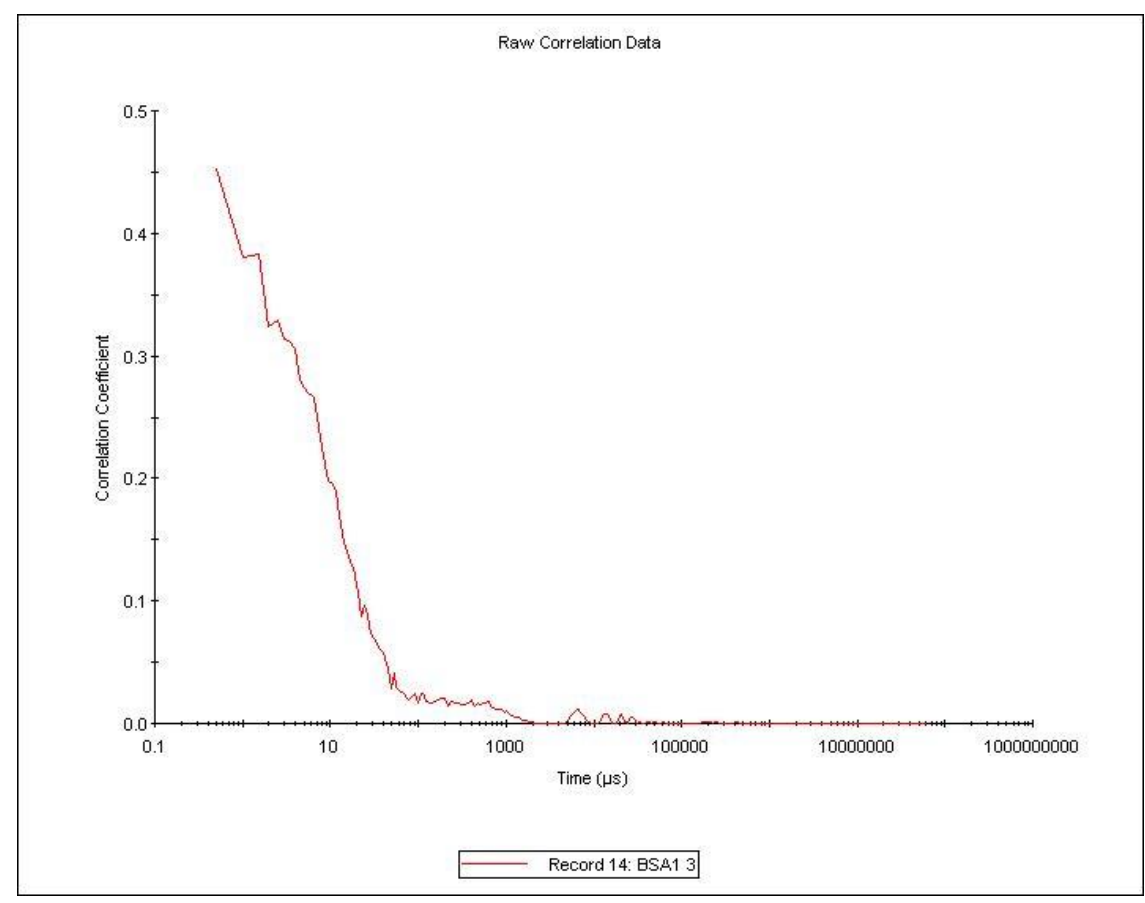

BSA $(15 \mu \mathrm{M})$

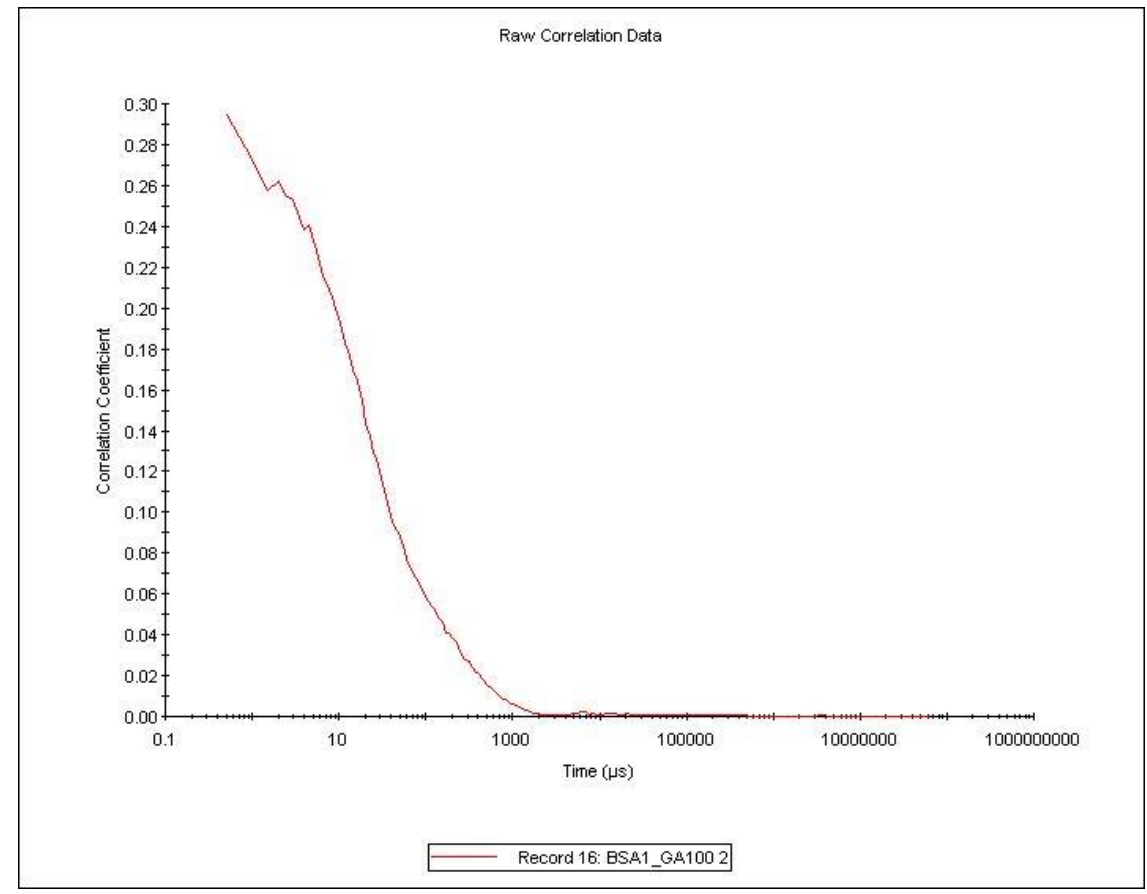

$2(100 \mu \mathrm{M})+\mathrm{BSA}(15 \mu \mathrm{M})$ 
Supporting Information

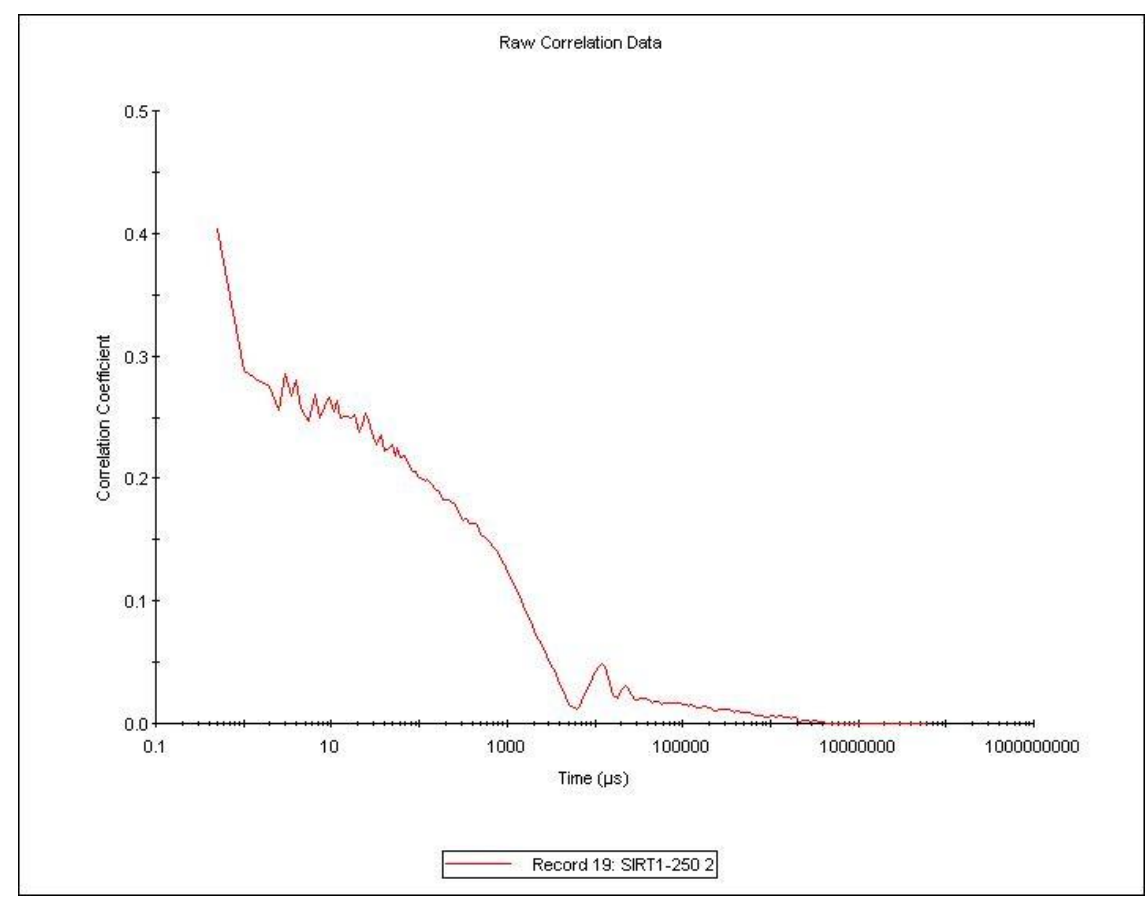

SIRT1 (250 nM)

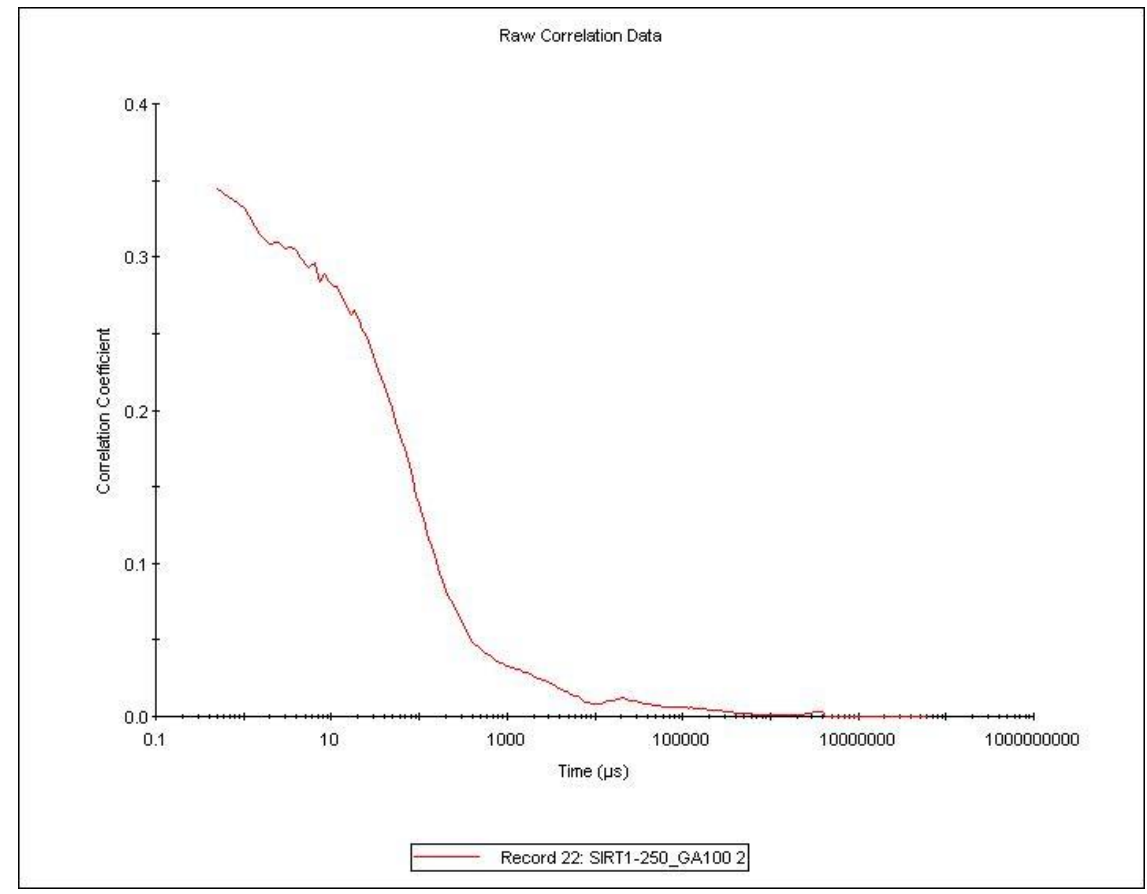

$2(100 \mu \mathrm{M})+\operatorname{SIRT} 1(250 \mathrm{nM})$ 


\section{Representative HPLC chromatograms}

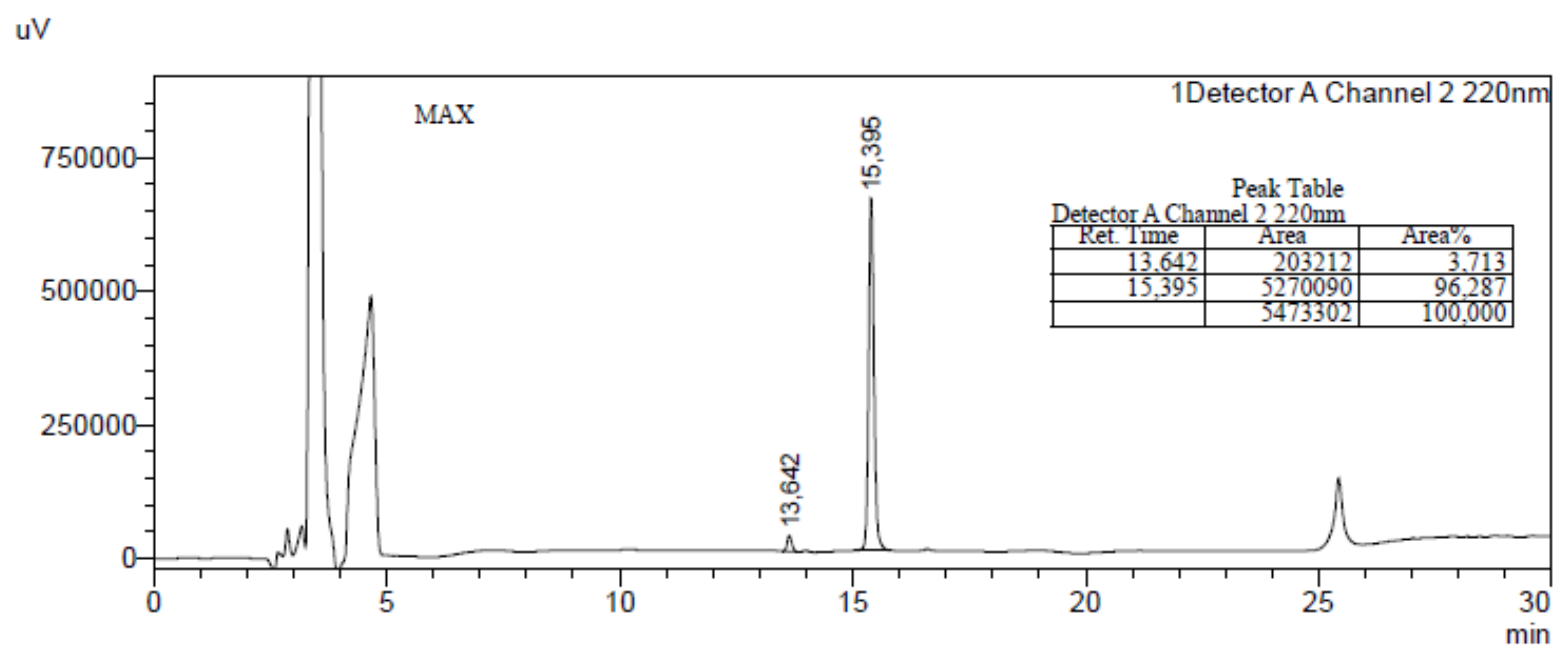

uV

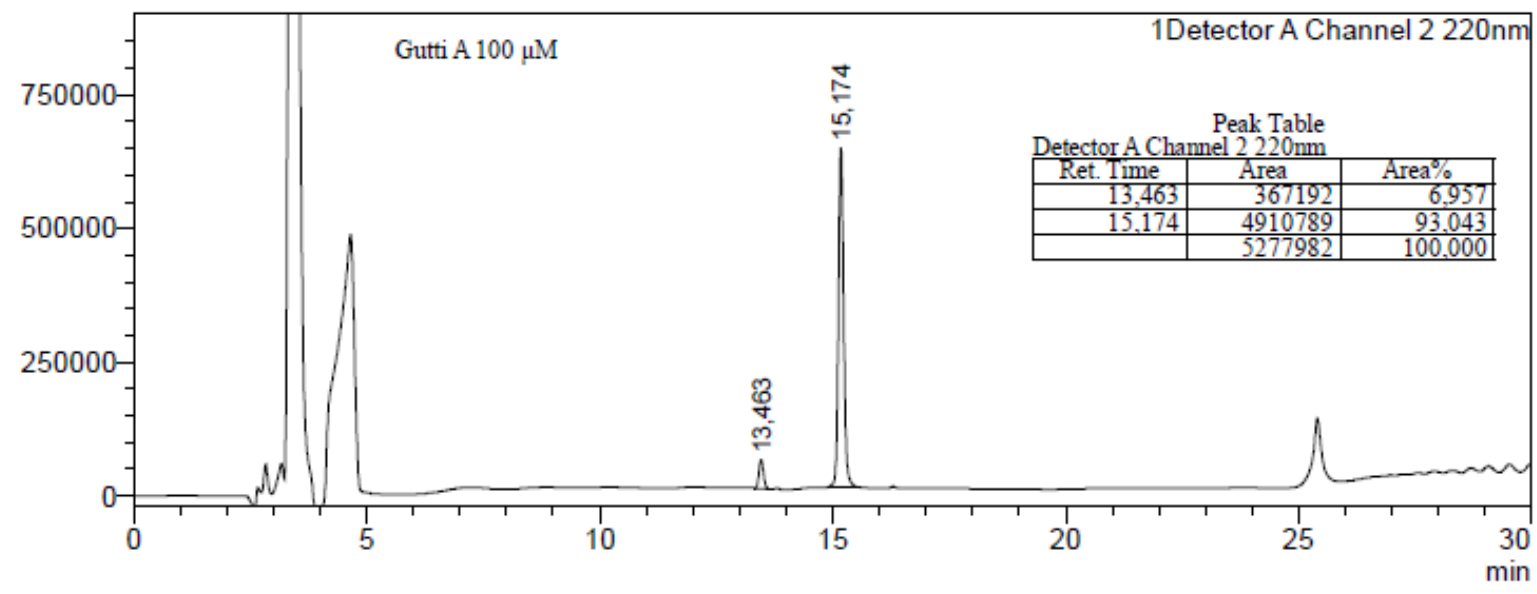

Figure S14. HPLC chromatograms of reaction mixtures in the presence of 0.01\% TX-100 without (top) or with (bottom) guttiferone A $2(100 \mu \mathrm{M})$. See experimental procedures for details. 